\title{
ZAKAZ DYSKRYMINACJI ZE WZGLĘDU NA WYZNANIE LUB ŚWIATOPOGLĄD W PRAWIE POLSKIM ${ }^{1}$
}

\section{WPROWADZENIE}

Polski system prawny zawiera liczne regulacje dotyczące zakazu dyskryminacji ze względu na religię (wyznanie) lub światopogląd (bezwyznaniowość). Są to zarówno regulacje traktujące w ogóle o zakazie dyskryminacji z jakiejkolwiek przyczyny, jak i gwarancje szczegółowe, dotyczące wyłącznie zakazu dyskryminacji z przyczyn religijno-światopoglądowych. Dotyczą one w ogóle życia publicznego, w jego zróżnicowanych aspektach - kulturalnego, politycznego, gospodarczego, społecznego itd., albo szczególnych aspektów życia publicznego jednostki, np. sfery zatrudnienia.

Odpowiednie postanowienia antydyskryminacyjne występują w aktach prawnych o różnym charakterze. Najistotniejsze są zawarte w aktach normatywnych prawa powszechnie obowiązującego. Z uwagi na hierarchiczny system źródeł prawa powszechnie obowiązującego, na plan pierwszy wysuwają się gwarancje zawarte w Konstytucji Rzeczypospolitej Polskiej z dnia 2 kwietnia 1997 r. ${ }^{2}$ oraz w ratyfiko-

${ }^{*}$ Dr hab., Zakład Prawa Wyznaniowego, Wydział Prawa i Administracji, Uniwersytet Warszawski, ul. Krakowskie Przedmieście 26/28, 00-927 Warszawa, e-mail: pawelborecki@ op.pl.

${ }^{1}$ Niniejszy tekst został opublikowany w wersji elektronicznej przez Polskie Towarzystwo Prawa Antydyskryminacyjnego pod adresem: http://www.ptpa.org.pl/public/files/ Dyskryminacja\%20ze\%20wzgl\%C4\%99du\%20na\%20wyznanie._pdf [dostęp: 20.10.2015].

${ }^{2}$ Dz. U. Nr 78, poz. 483 z późn. zm. 
wanych przez Polskę umowach międzynarodowych - w Paktach Praw Człowieka ONZ z 1966 r. ${ }^{3}$, w Konwencji o Ochronie Praw Człowieka i Podstawowych Wolności z 1950 r. (dalej: EKPCz) ${ }^{4}$, w traktatach stanowiących tzw. prawo pierwotne Unii Europejskiej ${ }^{5}$ oraz w tzw. wtórnym prawie europejskim. Z uwagi na doniosłość problemu dyskryminacji dla zainteresowanej jednostki lub grup ludzkich najważniejsze praktyczne znaczenie mają, jak się wydaje, gwarancje zakazu dyskryminacji ze względu na przekonania zawarte w prawie karnym, w prawie pracy oraz w tzw. ustawie antydyskryminacyjnej ${ }^{6}$.

Zakaz dyskryminacji ze względu na religię lub światopogląd znajduje swoje uzasadnienie aksjologiczne w koncepcji równej i niezbywalnej godności każdego człowieka jako podstawy jego wolności i praw, zawartej już w art. 1 Powszechnej Deklaracji Praw Człowieka ONZ z 1948 r. ${ }^{7}$, następnie w EKPCz (zob. art. 2 ust. 1, art. 3, art. 4 ust. 1 i 2), w Paktach Praw Człowieka ONZ (zob. arendy do Paktów), czy w obecnej polskiej Konstytucji z 1997 r. (art. 30 w związku z art. 31 i art. 32). Deklaracja ONZ z 1981 r. w sprawie wyeliminowania wszelkich form nietolerancji i dyskryminacji opartych na religii lub przekonaniach $^{8}$, zwana dalej Deklaracją ONZ 1981 r., w art. 3, głosi że [d]yskryminacja pomiędzy istotami ludzkimi na podstawie religii lub przekonań stanowi obraze godności ludzkiej [...]. Należy także odnotować, że Kościół Katolicki uznaje godność człowieka (osoby ludzkiej) za podwalinę wolności w sprawach religijnych począwszy od przyjęcia

${ }^{3}$ Międzynarodowy Pakt Praw Obywatelskich i Politycznych (Dz. U. z 1977 r. Nr 38, poz. 167), Międzynarodowy Pakt Praw Społecznych, Gospodarczych i Kulturalnych (Dz. U. z 1977 r. Nr 38, poz. 167).

${ }^{4}$ http://www.bip.ms.gov.pl/Data/Files/_public/bip/prawa_czlowieka/ets_006.pdf [dostęp: 25.06.2015].

${ }^{5}$ Zob.: Traktat o Unii Europejskiej (wersja skonsolidowana), Traktat o funkcjonowaniu Unii Europejskiej (wersja skonsolidowana), (Dz. Urz. C 326, 26/10/2012 P. 00010390), zob. także: http://eur-lex.europa.eu/legal-content/PL/TXT/?uri=celex:12012E/TXT [dostęp: 25.06.2015].

${ }^{6}$ Ustawa z dnia 3 grudnia 2010 r. o wdrożeniu niektórych przepisów Unii Europejskiej w zakresie równego traktowania (Dz. U. Nr 254, poz. 1700).

${ }^{7}$ http://libr.sejm.gov.pl/tek01/txt/onz/1948.html [dostęp: 25.06.2015].

${ }^{8}$ http://libr.sejm.gov.pl/tek01/txt/onz/1981.html [dostęp: 25.06.2015]. 
przez Sobór Watykański II w 1965 r. Deklaracji w sprawie wolności religijnej ${ }^{9}$.

Zakaz dyskryminacji ze względu na przekonania w sprawach religijnych, czy światopoglądowych, stanowi wzmocnienie zasady równości wobec prawa. Ma on charakter meta-prawa, nie wskazuje bowiem na „materialne” swobody i uprawnienia jednostek lub grup, lecz określa zasady urzeczywistnienia tych wolności i praw. W polskim prawie, rozumianym szerzej niż tylko jako prawo powszechnie obowiązujące, jest obecna definicja legalna dyskryminacji ze względu na religię i przekonania, przy tym dyskryminacja ta łączona jest z nietolerancją.

Według art. 2 ust. 2 Deklaracji ONZ z 1981 r. pod pojęciem ,nietolerancja i dyskryminacja oparta na religii lub przekonaniach" należy rozumieć jakiekolwiek rozróżnienie, wykluczenie, ograniczenie lub uprzywilejowanie oparte na religii lub przekonaniach, mające za swój cel albo za swój skutek zniesienie lub podkopanie uznania, korzystania lub urzeczywistnienia praw człowieka i podstawowych wolności na zasadzie równości. Przyjęta definicja jest szeroka, co wzmacnia jej gwarancyjny charakter i służy jej uniwersalizacji. W szczególności przyjęto $\mathrm{w}$ niej kryterium religii i przekonań, które zasadnie należy odnieść, zgodnie z wykładnią systemową i celowościową, nie tylko do przekonań w sprawach religijnych. Przekonania takie, zgodnie z utrwaloną wykładnią w doktrynie prawa konstytucyjnego i wyznaniowego, orzecznictwie sądowym sądów najwyższych, czy sądów konstytucyjnych praworządnych państw demokratycznych oraz zgodnie z interpretacją przyjętą w międzynarodowych aktach prawnych w sprawie wolności i praw człowieka obejmują również takie przekonania jak: agnostycyzm, ateizm, świecki humanizm itp., które powinny być traktowane na równi $\mathrm{z}$ religią, w węższym rozumieniu tego terminu. Analizowana definicja odwołuje się nie tylko do kryterium celu działania, ale także w równym stopniu, alternatywnie, do kryterium skutku. Jest to o tyle istotne, że wykazanie szczególnie przed organem sądowym, że sprawca, zwłaszcza państwo, celowo zmierzało do ograniczenia w korzystaniu z wolności i praw człowieka ze względu na religię lub przekonania na zasadzie równości może być bardzo trudne, wręcz niemożliwe.

${ }^{9}$ http://www.zaufaj.com/sobor-vaticanum-ii-/359.html [dostęp: 25.06.2015]. 
Nietolerancji i dyskryminacji została przeciwstawiona w omawianej definicji zasada równości. Obowiązek powstrzymania się przed dyskryminacją został zakreślony w art. 2 ust. 1 Deklaracji z $1981 \mathrm{r}$. bardzo szeroko i bez żadnych zastrzeżeń, tzn. wobec państw, instytucji, grup osób albo jednostek. Jest to ujęcie, jak się wydaje nazbyt szerokie - nierealistyczne i mogące budzić wątpliwości z punktu widzenia np. wolności wyznawania religii $\mathrm{w}$ aspekcie kolektywnym (autonomii i niezależności wspólnot religijnych). Wspólnota religijna, czy wspólnota światopoglądowa ma prawo różnicować status jednostek z nią związanych, na podstawie kryterium religii (wyznania), czy światopoglądu. Ma prawo dobierać sobie personel w oparciu o szczególne kryteria lojalności. Najistotniejsze jest to, aby zakaz dyskryminacji respektowały państwa, a szerzej - podmioty sprawujące władzę publiczną.

Należy zwrócić uwagę, że powyższa definicja ma ograniczoną skuteczność formalno-prawną. Występuje ona jedynie w Deklaracji ONZ z 1981 r., a Deklaracja nie jest prawnie wiążącym aktem prawa międzynarodowego; nie jest umową międzynarodową, w szczególności umową międzynarodową ratyfikowaną. Siła oddziaływania Deklaracji wynika przede wszystkim z autorytetu ONZ, z faktu, że uzyskała ona szerokie poparcie na forum Zgromadzenia Ogólnego ONZ i ma niewątpliwe walory intelektualne, aksjologiczne i prawne, ale właśnie tylko walory. Deklarację ONZ z 1981 r. można uznać za przykład tzw. „soft law”. Do powyższej definicji dyskryminacji ze względu na religię (wyznanie) lub przekonania (w sprawach religijnych) odwoływano się, omawiając liczne kwestie szczegółowe niniejszego opracowania.

Jednym z zasadniczych celów zakazu dyskryminacji ze względu na wspomniane kryteria jest zapewnienie pełnej wolności przyjmowania, zmiany i wyznawania przekonań w sprawach religijnych, czy szerzej - światopoglądowych, tak indywidualnie jak i zbiorowo, prywatnie i publicznie (art. 2 w związku z art. 1 Deklaracji ONZ z 1981 r.).

Obowiązujące powszechnie w Polsce prawo formułuje legalne definicje dyskryminacji bezpośredniej i dyskryminacji pośredniej. Zgodnie z art. 3 pkt 1 ustawy z dnia 3 grudnia 2010 r. o wdrożeniu niektórych przepisów Unii Europejskiej w zakresie równego traktowania, dyskryminacja bezpośrednia to sytuacja, w której osoba fizyczna ze względu na płeć, rasę, pochodzenie etniczne, narodowość, religię, 
wyznanie, światopogląd, niepełnosprawność, wiek lub orientację seksualną jest traktowana mniej korzystnie niż jest, była lub byłaby traktowana inna osoba w porównywalnej sytuacji. Pod pojęciem dyskryminacji pośredniej ustawodawca rozumie sytuację, w której dla osoby fizycznej ze względu na płeć, rasę, pochodzenie etniczne, narodowość, religię, wyznanie, światopogląd, niepełnosprawność, wiek lub orientację seksualną na skutek pozornie neutralnego postanowienia, zastosowanego kryterium lub podjętego działania występują lub mogłyby wystąpić niekorzystne dysproporcje lub szczególnie niekorzystna dla niej sytuacja, chyba że postanowienie, kryterium lub działanie jest obiektywnie uzasadnione ze względu na zgodny z prawem cel, który ma być osiągnięty, a środki służące osiągnięciu tego celu są właściwe i konieczne (art. 3 pkt 2) ${ }^{10}$. Należy podkreślić, że są to najszersze definicje dyskryminacji występujące $\mathrm{w}$ polskim prawie, i w zasadzie swoim zakresem znaczeniowym obejmują także definicję zawartą w Deklaracji ONZ z 1981 r.

We współczesnej Polsce prawne gwarancje zakazu dyskryminacji na podstawie kryteriów wyznaniowo-światopoglądowych są szczególnie istotne. Po II wojnie światowej, w następstwie zmiany granic państwa i utraty tzw. kresów wschodnich, przesiedleń ludności, w tym wysiedlenia ludności niemieckiej, wreszcie na skutek Holokaustu i emigracji ludności żydowskiej, doszło do bardzo daleko idącego ujednolicenia populacji pod względem etnicznym i wyznaniowym. Polska stała się wręcz krajem jednolitym narodowościowo i religijnie, a stereotyp „Polaka katolika” znalazł szczególnie wyraźne materialne podstawy ${ }^{11}$. Po 1944 r. czynniki polityczne - tzn. rządy kolejnych ekip komunistycznych, urzeczywistniających marksistowskie zasady stosunku państwa do religii - stanowiły barierę, aby dominacja socjologiczna katolicyzmu w społeczeństwie polskim bezpośrednio nie skutkowała dyskry-

${ }^{10}$ Por. art. $18^{3 \mathrm{a}} \S 3$ i $\S 4$ ustawy z dnia 26 czerwca 1974 r. Kodeks pracy (tekst jedn. Dz. U. z 2014 r, poz. 1502 z późn. zm.) oraz art. 2 ust. 2 w związku z art. 1 Dyrektywy Rady 2000/78/WE z dnia 27 listopada 2000 r. ustanawiającej ogólne warunki ramowe równego traktowania w zakresie zatrudnienia i pracy (Dz. Urz. UE. L.2000.303.16; Dz. Urz. UE-sp.05-4-79).

${ }^{11}$ Powyższy problem szeroko omawia Stanisław Obirek, patrz: Polak katolik? (Warszawa: Wydawnictwo CiS, 2015). 
minacją osób innych wyznań lub niewierzących. Co więcej, w państwie tzw. realnego socjalizmu, propagującym w praktyce światopogląd materialistyczny, to właśnie osoby wierzące były dyskryminowane w życiu publicznym; nierzadko, zwłaszcza do końca lat 70-tych, nawet prześladowane. Próbę znalezienia ,zdrowej” równowagi, nawiązującej do uniwersalnych standardów w dziedzinie wolności i praw człowieka, w tym wolności myśli, sumienia i wyznania, czy zakazu dyskryminacji ze względu na religię, czy światopogląd stanowiły uchwalone jeszcze przez Sejm PRL IX kadencji i wciąż obowiązujące ustawy z dnia 17 maja 1989 r.: o stosunku Państwa do Kościoła Katolickiego w Rzeczypospolitej Polskiej ${ }^{12}$ oraz o gwarancjach wolności sumienia i wyznania ${ }^{13}$.

Po przełomie ustrojowym w 1989 r. znikły nie tylko ograniczenia prawne, ale także ograniczenia faktyczne, stanowiące zaporę dla dominacji katolicyzmu w życiu publicznym. Pluralizm wyznaniowy jest wciąż ograniczony, aczkolwiek w ostatnich latach pojawiły się tendencje narastającej laicyzacji społeczeństwa polskiego.

Zgodnie z badaniami Instytutu Gallupa z 2014 r. Polska to jeden z najbardziej religijnych, jeśli nie najbardziej religijny, kraj w Europie. Za religijnych uznało się aż $86 \%$ badanych $^{14}$. W statystyce wyznaniowej $\mathrm{w}$ Polsce nadal dominuje katolicyzm ${ }^{15}$. Nie występuje znaczący

12 Tekst jedn. Dz. U. z 2013 r, poz. 1169 z późn. zm.

${ }^{13}$ Tekst jedn. Dz. U. z 2005 r. Nr 231, poz. 1965 z późn. zm.

${ }^{14} \mathrm{http} / /$ www.eurel.info/spip.php\%3Farticle2588\&usg=ALkJrhgExG0-kz03ZEuX80qK ZQ3zoOpV9A [dostęp: 13.05.2015].

${ }^{15} \mathrm{Wg}$ badań przeprowadzonych na grupie reprezentacyjnej nt. przynależności wyznaniowej w ramach Narodowego Spisu Powszechnego Ludności i Mieszkań 2011 na ogólną populację Polski liczącą 38512000 osób udzieliło odpowiedzi o przynależność wyznaniową 35151000 osób, czyli 91,27\%. Odmówiło odpowiedzi na pytanie o wyznanie 2734000 osób czyli 7,1\%; nie ustalono odpowiedzi w przypadku 627000 osób (1,63\%). Wśród udzielających odpowiedzi na pytanie o wyznanie najwięcej, czyli 33729000 osób zaliczyło się do Kościoła Katolickiego obrządku łacińskiego (87,58\%). Do Kościoła prawosławnego zaliczyło się 156000 osób (0,41\%); do Związku Wyznania Świadków Jehowy - 137000 osób (0,36\%); do Kościoła Ewangelicko-Augsburskiego - 71000 (0,18\%); do Kościoła Katolickiego obrządku bizantyjsko-ukraińskiego - 33000 (0,09\%); do Kościoła Zielonoświątkowego - 26000 osób (0,07\%), do Kościoła Starokatolickiego Mariawitów - $10000(\mathbf{0 , 0 3 \%})$; inne - 59000 osób $(\mathbf{0 , 1 5 \%})$. Zadeklarowało brak przynależności do jakiegokolwiek wyznania 929000 osób czyli 2,41\% populacji. Zob.: Ludność. Stan i struk- 
wzrost wyznawców innych konfesji, może poza członkami związku wyznaniowego Świadków Jehowy ${ }^{16}$. Należy zarazem pamiętać, że współcześnie w Kościele Katolickim, czy w Polskim Autokefalicznym Kościele Prawosławnym, kryteria członkostwa są wyraźnie nie wyśrubowane ${ }^{17}$. Zatem formalna liczebność katolicyzmu w żadnym stopniu nie odzwierciedla, rzeczywistej aktywności religijnej ${ }^{18}$, czy tym bardziej internalizacji podstawowych zasad doktrynalnych i moralnych tego wyznania $^{19}$. Wzrost wyraźny, wręcz skokowy, miał miejsce natomiast w ostatnich latach w grupie szeroko rozumianych osób bezwyzna-

tura demograficzno-społeczna. Narodowy Spis Powszechny Ludności i Mieszkań 2011 (Warszawa: Główny Urząd Statystyczny, 2013), 99.

${ }^{16}$ Według deklaracji samego właściwego związku wyznaniowego w 2000 r. miał on liczyć 122575 osób, natomiast w 2011 r. - 129 270. Zob.: Wyznania religijne, stowarzyszenia narodowościowe i etniczne w Polsce 2009-2011 (Warszawa: Główny Urząd Statystyczny, 2013), 149.

${ }^{17}$ Kryterium przynależności do Kościoła Katolickiego, czy do Kościoła Prawosławnego, jest przede wszystkim chrzest $\mathrm{z}$ wody. W warunkach polskich dokonywany jest on przede wszystkim w odniesieniu do niemowląt. Zarazem zainteresowani wystąpieniem z Kościoła Katolickiego (apostaci) napotykają częstokroć na liczne trudności ze strony właściwych duchownych tego Kościoła (podobnie jak byli wyznawcy Światków Jehowy). Zob. także Zasady postępowania w sprawie formalnego aktu wystapienia z Kościoła [Konferencji Episkopatu Polski] - http://episkopat.pl/dokumenty/pozostale/5075.1,Zasady_postepowania_w_sprawie_formalnego_aktu_wystapienia_z_Kosciola.html [dostęp: 22.07.2015].

${ }^{18}$ Wg Instytutu Statystyki Kościoła Katolickiego w 2013 r. w niedzielnych Mszach św. uczestniczyło średnio w skali kraju 39,1\% członków Kościoła Katolickiego (Dominicantes), natomiast do Komunii św. przystąpiło (Comunicantes) - 16,3\% wiernych. W ciągu 10 lat liczba praktykujących regularnie katolików zmniejszyła się o ok. 2 mln. W dziedzinie poziomu praktyk religijnych występują duże różnice regionalne. W 2013 r. w diecezji tarnowskiej odpowiednie wskaźniki praktyk religijnych wyniosły $69 \%$ oraz $23,7 \%$, natomiast w diecezji szczecińsko-kamieńskiej - 24,3\% i 10,9\% - zob. http://www.iskk.pl/kosciolnaswiecie/193dominicantes-2013.html [dostęp: 22.07.2015].

${ }^{19} \mathrm{Wg}$ badań sondażowych w 2015 r. zadeklarowało wiarę w Boga bez wątpliwości 56\% badanych, wiarę w Boga ale z wątpliwościami 27\% (zatem ogółem odsetek wierzących wśród badanych to $\mathbf{8 3 \%}$ ); wiarę w: sąd ostateczny $\mathbf{7 0 \%}$ badanych; w niebo $-\mathbf{7 0 \%}$; w nieśmiertelną duszę człowieka - 69\%; w życie wieczne - 66\%; w przeznaczenie $-66 \%$; w zmartwychwstanie zmarłych - $\mathbf{6 2 \%}$, w obciążenie człowieka grzechem pierworodnym $\mathbf{5 9 \%}$, w piekło $\mathbf{- 5 6 \%}$, w posiadanie duszy przez zwierzęta $-\mathbf{3 6} \%$, w reinkarnację $-\mathbf{3 0 \%}$. Ponadto $61 \%$ respondentów wierzy, że każdy może być zbawiony, 36\% wierzy, że po śmierci idziemy do nieba, do piekła lub do czyśćca - zob.: http://www.cbos.pl/SPISKOM. POL/2015/K_029_15.PDF [dostęp: 23.07.2015]. 
niowych ${ }^{20}$. Należy jednak podkreślić, że w ostatnim dziesięcioleciu wyraźnie zaznaczył się proces sekularyzacji społeczeństwa, a zarazem prywatyzacja przekonań w sprawach religijnych. Mówiąc potocznie: wyznania religijne w Polsce w ograniczonym stopniu mogą skutecznie „patrzeć na ręce” sobie nawzajem i władzy publicznej różnych szczebli. Związana z tym jest też częstokroć obawa mniejszości religijnych przed potencjalną presją ze strony Kościoła Katolickiego oraz związanych z nim decydentów - wręcz swoisty „kompleks getta”. Zaktywizował się natomiast przynajmniej od dekady tzw. ruch laicki, mający charakter antyklerykalny i reprezentujący głownie światopogląd niereligijny.

\section{ZAKAZ DYSKRYMINACJI}

ZE WZGLĘDU NA RELIGIĘ LUB PRZEKONANIA W KONSTYTUCJI RZECZYPOSPOLITEJ POLSKIEJ Z 1997 R.

Konstytucja RP z 1997 r. formułuje ogólny zakaz dyskryminacji w art. 32 ust. 2, zawartym w Rozdziale II pod nazwą: „Wolności, prawa i obowiązki człowieka i obywatela”, w części „Zasady ogólne”: [n]ikt nie może być dyskryminowany $w$ życiu politycznym, społecznym i gospodarczym z jakiejkolwiek przyczyny. Ustawa zasadnicza nie formułuje wprost definicji analizowanego zjawiska, w tym zakresie odsyła do ustawodawstwa zwykłego i innych aktów normatywnych. Zakaz konstytucyjny obejmuje m.in. niedopuszczalność dyskryminacji ze względu na religię (wyznanie), światopogląd, czy bezwyznaniowość, lecz niewymienienie kryterium religii (wyznania), świato-

${ }^{20} \mathrm{Wg}$ danych GUS z 2011 r. poza oficjalnie działającymi związkami wyznaniowymi, które same przekazywały Urzędowi dane dotyczące liczby swoich wyznawców, miało pozostawać ok. 4200000 mieszkańców Polski, czyli 10,9\% populacji - zob. Wyznania religijne, stowarzyszenia narodowościowe i etniczne w Polsce 2009-2011, 15. Wg. danych GUS na rok 2005 r. liczba osób bezwyznaniowych miała wynosić ok. 3080 000, czyli $\mathbf{8 , 1 \%}$ ludności Polski [zob.: Wyznania religijne, stowarzyszenia narodowościowe $i$ etniczne w Polsce 2003-2005, red. Grzegorz Gudaszewski (Warszawa: Główny Urząd Statystyczny, 2007), 15], natomiast w 1999 r. bezwyznaniowcy mieli stanowić ok. 3016000 osób, czyli 7,8\% ludności kraju [Wyznania religijne, stowarzyszenia narodowościowe i etniczne w Polsce 1997-1999, red. Lucjan Adamczuk, Grzegorz Gudaszewski (Warszawa: Główny Urząd Statystyczny, 2000), 14]. 
poglądu, względnie bezwyznaniowości osłabia wymowę gwarancyjną omawianego przepisu. Ustrojodawca nie sprecyzował również, na kim ciąży obowiązek niedyskryminacji. Domniemywać należy, że obowiązek ten dotyczy organów władzy publicznej, czy szerzej - podmiotów sprawujących władzę publiczną. Natomiast można mieć wątpliwości, czy w sposób bezwarunkowy obowiązek ten ciąży na podmiotach prywatnych, skoro w art. 32 ust. 3 sfera życia osobistego nie jest wymieniona. Ochrona wynikająca z zakazu dyskryminacji dotyczy każdego, czyli zarówno osób fizycznych, niezależnie od spełnienia kryterium obywatelstwa, jak i osób prawnych, bowiem art. 32 ust. 3 Konstytucji zlokalizowany jest przed częścią Rozdziału II Konstytucji pt. „Wolności i prawa osobiste". Zakaz dyskryminacji jest negatywnym korelatem zasady równości wyrażonej w art. 32 ust. 1 i 2 Konstytucji; przepisy te stanowią, że wszyscy są wobec prawa równi i wszyscy maja prawo do równego traktowania przez władze publiczne. Treść art. 32 Konstytucji została wzmocniona poprzez wyraźne nadanie Konstytucji statusu aktu prawa powszechnie obowiązującego o najwyższej mocy prawnej (art. 8 ust. $1 \mathrm{w}$ związku z art. 87 ust. 1 Konstytucji), który stosuje się bezpośrednio, chyba że sama Konstytucja stanowi inaczej (art. 8 ust. 2). Jednostka może zatem bezpośrednio powoływać się na zakaz dyskryminacji wynikający z art. 32 ust. 3 ustawy zasadniczej przed organami stosującymi prawo.

Zakaz dyskryminacji, o którym mowa w art. 32 ust. 2 Konstytucji, przynajmniej teoretycznie, może być podważony, ale jedynie w zgodzie z przesłankami określonymi w art. 31 ust. 3 ustawy zasadniczej. Ograniczenia w zakresie korzystania z konstytucyjnych wolności i praw mogą być ustanawiane tylko w ustawie i tylko wtedy, gdy są konieczne w demokratycznym państwie, dla zagwarantowania jego bezpieczeństwa lub porządku publicznego, bądź dla ochrony środowiska, zdrowia i moralności publicznej, albo dla ochrony wolności i praw innych osób. Wprowadzane ustawą ograniczenia te nie mogą naruszać istoty wolności i praw. Należy zwrócić uwagę na kryterium „konieczności” (niezbędności) w „demokratycznym państwie”. Kryterium to jest bardzo zbliżone do kryterium „demokratycznego społeczeństwa" występującego jako wyznacznik ograniczenia wolności i praw gwarantowanych przez EKPCz. Zgodnie z utrwalonym orzecznictwem 
organów strasburskich demokratyczne społeczeństwo to społeczeństwo pluralistyczne. Dlatego też ewentualne odstępstwa od zakazu dyskryminacji nie mogą mieć na celu standaryzacji religijno-światopoglądowej społeczeństwa. W tym miejscu należy mocno podkreślić, że to przede wszystkim na ustawodawcy i na organach stosujących prawo ciąży obowiązek konkretyzacji zakazu, o którym mowa w art. 32 ust. 3 Konstytucji.

Jednakże w Konstytucji RP z 1997 r. mamy do czynienia z odstąpieniem od ściśle pojętej zasady egalitaryzmu wspólnot religijnych oraz wspólnot zrzeszających jednostki na podstawie innego rodzaju światopoglądu niż religijny, potocznie zwanych organizacjami laickimi. Wyraźna dystynkcja pomiędzy związkami wyznaniowymi a organizacjami laickimi pozwala mówić o dyskryminacji tych drugich. Jest to o tyle znamienne, że z preambuły konstytucyjnej wynika paradygmat równości obywateli wyznających religię (wierzących w Boga) i posiadających światopogląd niefideistyczny. Wskazują na to słowa: [...] my, Naród Polski - wszyscy obywatele Rzeczypospolitej zarówno wierzący w Boga będacego źródtem prawdy, sprawiedliwości, dobra i piękna, jak $i$ nie podzielajacy tej wiary, a te uniwersalne wartości wywodzacy z innych źródel, równi w prawach $i$ w powinnościach wobec dobra wspólnego-Polski [...]. W części normatywnej Konstytucji tymczasem organizacje laickie, jako takie, nie są w ogóle dostrzegane. Statusowi kościołów i innych związków wyznaniowych oraz zasadom ich relacji z państwem poświęcony jest art. 25 Konstytucji, zajmujący bardzo wysokie miejsce w systematyce ustawy zasadniczej, tzn. w Rozdziale I pt. „Rzeczypospolita”, a jedną z ustrojowych zasad relacji między państwem a związkami wyznaniowymi jest zasada bilateralizmu, która czyni wspólnoty religijne niejako partnerami państwa, szczególnie w dziedzinie regulacji położenia prawnego związków wyznaniowych. Poza tym ustrojodawca w pewnej mierze dyskryminuje osoby wyznające światopogląd niereligijny w zakresie gwarancji ich swobód i uprawnień w szeroko rozumianej dziedzinie wolności w sprawach religijnych (wolności myśli, sumienia i wyznania). Optymalne gwarancje konstytucyjne w zakresie wolności sumienia i religii, które formułuje art. 53 ust. 1 Konstytucji, posiadają jedynie osoby wyznające religie, zaś szczegółowe gwarancje wyznawania religii przez jednostkę zawarte są 
zwłaszcza w art. 53 ust. 2-4. Trzeba mieć na uwadze, że analizowany art. 53 pomija wolność zmiany religii lub przekonań, mówi jedynie o wolności przyjmowania religii.

Zgodnie z art. 53 ust. 4 Konstytucji w szkole, zwłaszcza w szkole publicznej, może być nauczana tylko religia, i tylko związku wyznaniowego o uregulowanej sytuacji prawnej, czyli wpisanego przynajmniej do rejestru kościołów i innych związków wyznaniowych. Zatem zorganizowane nauczanie światopoglądu niereligijnego w szkolnictwie publicznym jest w Polsce konstytucyjnie, a także ustawowo niedopuszczalne $^{21}$. Osoby wyznające światopogląd niereligijny mogą poszukiwać konstytucyjnych podstaw dla swobody jego ekspresji np. w art. 54 Konstytucji, którego przepis gwarantuje wolność wyrażania poglądów. Przepis ten ma wszakże całkiem inny cel; ma on gwarantować wolność środków masowego przekazu.

Egalitaryzm, czyli niedyskryminacja w postrzeganiu wierzących i niewierzących przez ustrojodawcę, jest natomiast czytelny w przepisie art. 48 ust. 1 ustawy zasadniczej, zapewniającym rodzicom prawo do wychowania dzieci zgodnie z ich przekonaniami, pod warunkiem

${ }^{21}$ Art. 12 ustawy z dnia 7 września 1991 o systemie oświaty (tekst jedn. Dz. U. z 2015 r., poz. 2156 z późn. zm.) stanowi: 1. Publiczne przedszkola, szkoły podstawowe i gimnazja organizują naukę religii na życzenie rodziców, publiczne szkoły ponadgimnazjalne na życzenie bądź rodziców, bądź samych uczniów; po osiagnięciu petnoletności o pobieraniu nauki religii decyduja uczniowie. 2. Minister właściwy do spraw oświaty $i$ wychowania w porozumieniu z władzami Kościoła Katolickiego i Polskiego Autokefalicznego Kościoła Prawosławnego oraz innych kościołów i związków wyznaniowych określa, $w$ drodze rozporządzenia, warunki i sposób wykonywania przez szkoty zadań, o których mowa w ust. 1. Co więcej zgodnie z preambułą wspomnianej ustawy nauczanie i wychowanie w RP ma respektować chrześcijański system wartości. Czyli partykularne wartości religijne w szkolnictwie publicznym a także prywatnym nie powinny być podważane. Zgodnie z rozporządzeniem z dnia 14 września 1992 r. w sprawie warunków i sposobu organizowania nauki religii w publicznych przedszkolach i szkołach (Dz. U. Nr 36, poz. 155 z późn. zm.) w publicznych szkołach (z wyjątkiem szkół wyższych) może być nauczana alternatywnie z religią także tzw. etyka. Etyka nie może być nauczana w przedszkolach. Jest to jednak przedmiot o charakterze nieświatopoglądowym. W praktyce lekcje religii niekatolickiej organizowane są w szkołach publicznych na Śląsku Cieszyńskim (luteranizm) oraz w niektórych rejonach Podlasia (prawosławie). W pozostałych rejonach Polski inne wyznania incydentalnie nauczają swej religii w szkołach i przedszkolach publicznych. Prowadzą one nauczanie przede wszystkim w pozaszkolnych punktach katechetycznych. Uczestnictwo dzieci w prowadzonej tam nauce religii wymaga zdecydowanie więcej wysiłku niż uczestnictwo w katechezie szkolnej. 
wszakże, że wychowanie to uwzględnia stopień dojrzałości dziecka, jego wolność sumienia i wyznania oraz przekonania. Ponadto egalitaryzm jest czytelny w art. 53 ust. 6 Konstytucji, zabraniającym zmuszania kogokolwiek, zatem także dzieci, zarówno do uczestniczenia jak $\mathrm{i}$ do nieuczestniczenia $\mathrm{w}$ praktykach religijnych. W istocie rzeczy „najsilniejszą” gwarancją niedyskryminacji ze względu na przekonania religijno-światopoglądowe jest zawarty w art. 25 ust. 2 Konstytucji nakaz zachowania bezstronności, czyli neutralności światopoglądowej przez władze publiczne. Ponadto podobne znaczenie posiada służący niedyskryminacji ze względu na religię (wyznanie) czy światopogląd (bezwyznaniowość) art. 53 ust. 7 ustawy zasadniczej, gwarantujący tzw. prawo do milczenia w sprawach religijno-światopoglądowych. Jednakże to uprawnienie jest ujęte dosyć wąsko; obliguje jedynie organy władzy publicznej, natomiast nie jest wiążące dla innych podmiotów, np. dla pracodawców, a tym bardziej dla związków wyznaniowych, bowiem analizowany przepis stanowi, że nikt nie może być obowiązany przez organy władzy publicznej do ujawnienia swego światopoglą$\mathrm{du}$, przekonań religijnych ani wyznania. Konkludując, $\mathrm{z}$ tego przepisu wynika, że państwo - w szerokim tego słowa rozumieniu - w ogóle nie powinno się interesować wyznaniem, czy szerzej - światopoglądem osób pozostających pod jego władztwem ${ }^{22}$.

Podsumowując rozważania o konstytucyjnych gwarancjach zakazu dyskryminacji ze względu na religię (wyznanie) lub światopogląd (bezwyznaniowość), podkreślić należy, że nasuwają się paradoksalne konstatacje i wnioski. Obowiązująca Konstytucja RP formułując w art. 32 ust. 3 zakaz dyskryminacji, m.in. ze względu na szeroko rozumiane przekonania w sprawach religijnych, sama nie urzeczywistnia konsekwentnie owej dyrektywy w swej treści. Jest to efekt zarówno przemilczeń ustrojodawcy, jak i pozytywnych treści przepisów wyznaniowych Konstytucji. Osobom wierzącym ustawa zasadnicza zapewnia wyraźnie lepsze gwarancje swobód w sprawach religijnych, niż osobom wyznającym światopogląd niereligijny. Nie dostrzega się zupełnie i ignoruje w przepisach Konstytucji tzw. organizacje laickie, zarazem dokonując nadmiernej ustrojowej aprecjacji związków wyznaniowych. W świetle

${ }^{22}$ Por. Michał Pietrzak, Prawo wyznaniowe (Warszawa: LexisNexis, 2010), 96. 
definicji dyskryminacji ze względu na religię lub przekonania, zawartej w Deklaracji ONZ z 1981 r., a tym bardziej kierując się definicjami dyskryminacji zawartymi w ustawie ,antydyskryminacyjnej”, można w Polsce mówić w istocie rzeczy o - zamierzonej czy nie - konstytucyjnie nierówno prawnej pozycji osób wyznających światopogląd niereligijny (niewierzących, czy bezwyznaniowców).

\section{ZAKAZ DYSKRYMINACJI W WIĄŻĄCYCH POLSKĘ AKTACH PRAWA MIĘDZYNARODOWEGO I UNIJNEGO.}

Zgodnie z art. 9 Konstytucji z 1997 r. Rzeczypospolita Polska przestrzega wiążącego ją prawa międzynarodowego. Obejmuje ono poza aktami prawa stanowionego także zwyczaje międzynarodowe. Kwalifikowaną formą aktów prawa stanowionego w dziedzinie prawa międzynarodowego są umowy międzynarodowe, szczególnie te podlegające ratyfikacji. Zgodnie z art. 91 ust. 1 Konstytucji RP ratyfikowana umowa międzynarodowa, po jej ogłoszeniu w Dzienniku Ustaw Rzeczypospolitej Polskiej, stanowi część krajowego porządku prawnego i jest bezpośrednio stosowana, chyba że jej stosowanie jest uzależnione od wydania ustawy. Umowa międzynarodowa podlegająca ratyfikacji za zgodą wyrażoną w ustawie, lokuje się w hierarchicznym systemie źródeł prawa bezpośrednio po Konstytucji. Ma pierwszeństwo przed ustawą, jeśli ustawy tej nie da się pogodzić z umową (art. 91 ust. 2). Ponadto, jeżeli wynika to $\mathrm{z}$ ratyfikowanej przez Polskę umowy konstytuującej organizację międzynarodową, prawo przez nią stanowione jest stosowane bezpośrednio, mając pierwszeństwo w przypadku kolizji z ustawami.

1. UNIWERSALNE STANDARDY PRAWA MIĘDZYNARODOWEGO W ZAKRESIE ZWALCZANIA DYSKRYMINACJI ZE WZGLĘDU NA RELIGIĘ LUB ŚWIATOPOGLĄD

Zgodnie z fundamentalnym artykułem 2 Powszechnej Deklaracji Praw Człowieka ONZ z 1948 r. każda osoba uprawniona jest do 
korzystania ze wszystkich praw i wolności ogłoszonych w Deklaracji bez jakiejkolwiek różnicy, zwłaszcza ze względu na rasę, kolor skóry, płeć, język, religię, poglądy polityczne lub inne, pochodzenie narodowe lub społeczne, majątek, urodzenie lub z jakiejkolwiek innej przyczyny (ang. or other status; franc. ou de toute autre situation). Szczególne znaczenie nadano w art. 18 Deklaracji prawu do wolności myśli, wolność sumienia i religii ${ }^{23}$, zaś dodatkową gwarancję niedyskryminacji zawarto w art. 7 tego aktu, w którym czytamy: Wszyscy sa równi wobec prawa i sa uprawnieni bez jakiejkolwiek dyskryminacji do równej ochrony prawnej. Wszyscy są uprawnieni do równej ochrony przed jakąkolwiek dyskryminacja sprzeczna z niniejszą Deklaracją oraz przed jakimkolwiek podżeganiem do takiej dyskryminacji ${ }^{24}$. Powszechna Deklaracja Praw Człowieka, jak wykazały wieloletnie doświadczenia w odwoływaniu się do jej przepisów, wyznaczyła standardy w dziedzinie ochrony wolności i praw, a także w dziedzinie zwalczania dyskryminacji, w wymiarze światowym oraz europejskim. Rzeczony akt znacząco wpłynął ponadto na język późniejszych aktów prawnych, gwarantujących wolności i prawa człowieka. Trzeba mieć świadomość, że siła oddziaływania Powszechnej Deklaracji opiera się jednak jedynie na znaczeniu moralno-filozoficznym i politycznym, bowiem Deklaracja nie jest umową międzynarodową, a tym bardziej - umową międzynarodową ratyfikowaną, wiążącą państwa członkowskie ONZ z punktu widzenia formalno-prawnego. Należy jednak odnotować, że współcześnie znacząca część specjalistów, zajmujących się profesjonalnie prawem międzynarodowym, uważa Deklarację za prawo zwyczajowe i wnioskują z tego o jej powszechnym obowiązywaniu.

W celu wzmocnienia ochrony wolności i praw człowieka, poprzez nadanie im charakteru prawnie wiążącego, w 1966 r. ONZ ustanowiła Międzynarodowe Pakty Praw Człowieka, będące aktami prawa międzynarodowego podlegającymi ratyfikacji przez poszczególne państwa

${ }^{23}$ Art. 18 Powszechnej Deklaracji Praw Człowieka ONZ głosi: Każda osoba ma prawo do wolności myśli, sumienia i religii; prawo to obejmuje wolność zmiany swej religii lub przekonań, jak również wolność manifestowania swej religii lub przekonań, indywidualnie lub wspólnie z innymi, publicznie lub prywatnie, poprzez nauczanie, praktyki religijne, sprawowanie kultu i rytuałów - http://libr.sejm.gov.pl/tek01/txt/onz/1948.html [dostęp: 2.07.2015]

${ }^{24}$ Zob. http://libr.sejm.gov.pl/tek01/txt/onz/1948.html [dostęp: 2.07.2015] 
i tym samym prawnie je wiążącymi (obligującymi). Prawodawca międzynarodowy zarazem czytelnie zaznaczył zobowiązanie państw do nadania postanowieniom Paktów charakteru realnego w porządku prawnym państw ${ }^{25}$, ponieważ postanowienia Paktów Praw Człowieka nie są bezpośrednio wiążące dla podmiotów spoza szeroko rozumianego aparatu państw, które Paktów nie ratyfikowały. Nie wiążą więc one w szczególności: kościołów i innych związków wyznaniowych, pracodawców prywatnych, stowarzyszeń religijnych i światopoglądowych.

W art. 2 ust. 1 Międzynarodowego Paktu Praw Obywatelskich i Politycznych (MPPOiP) została zawarta ogólna klauzula niedyskryminacji: - Każde z Państw Stron niniejszego Paktu zobowiąuje się przestrzegać i zapewnić wszystkim osobom, które znajduja się na jego terytorium i podlegaja jego jurysdykcji, prawa uznane $w$ niniejszym Pakcie, bez względu na jakiekolwiek różnice, takie jak: rasa, kolor skóry, płeć, język, religia, poglądy polityczne lub inne, pochodzenie narodowe lub społeczne, sytuacja majątkowa, urodzenie lub jakiekolwiek inne okoliczności. Zakres gwarancji niedyskryminacji odnosi się więc również do kryterium religii (wyznania) czy szerzej światopoglądu. Chroni on jednostkę działającą indywidualnie i kolektywnie w zakresie korzystania z prawa do wolności myśli, sumienia i religii (wyznania). Międzynarodowy Pakt Praw Obywatelskich i Politycznych w omawianej dziedzinie nawiązuje jednoznacznie do odpowiednich postanowień Powszechnej Deklaracji Praw Człowieka ONZ. Posta-

${ }^{25}$ Świadczy o tym m.in. treść art. 2 ust. 2 MPPOiP: Państwa Strony niniejszego Paktu zobowiąuja się podjać, zgodnie z własnym trybem konstytucyjnym i postanowieniami niniejszego Paktu, odpowiednie kroki majace na celu przyjęcie tego rodzaju środków ustawodawczych lub innych, jakie okaża się konieczne $w$ celu realizacji praw uznanych $w$ niniejszym Pakcie, jeżeli nie jest to już przewidziane w obowiazujacych przepisach prawnych lub w inny sposób.

3. Każde z Państw Stron niniejszego Paktu zobowiązuje się:

a) zapewnić każdej osobie, której prawa lub wolności uznane w niniejszym Pakcie zostaty naruszone, skuteczny środek ochrony prawnej, nawet gdy naruszenie to zostato dokonane przez osoby działajace w charakterze urzędowym;

b) zapewnić, aby prawo każdego człowieka do takiego środka ochrony prawnej byto określone przez wtaściwe władze sadowe, administracyjne lub ustawodawcze albo przez jakąkolwiek inna właściwa władzę, przewidziana w systemie prawnym danego Państwa, oraz rozwijać możliwości ochrony praw na drodze sądowej;

c) zapewnić realizowanie przez właściwe władze środków ochrony prawnej, gdy zostaty one przyznane. 
nowienia dotyczące wolności w sprawach religijnych uszczegóławia i znacząco rozbudowuje, w porównaniu z aktem z $1948 \mathrm{r}^{26}$

Analogiczna klauzula niedyskryminacyjna została zawarta w art. 2 ust. 2 Międzynarodowego Paktu Praw Gospodarczych, Społecznych i Kulturalnych. Należy zaznaczyć, że w art. 18 Paktu gwarantowana jest wolność myśli, sumienia i religii (wyznania) w szerokim ujęciu. Dokonując wykładni art. 18, Komitet Praw Człowieka ONZ stwierdził, iż chroni teistyczne, nie-teistyczne $i$ ateistyczne przekonania, jak też prawo do niewyznawania żadnej religii czy przekonań. Terminy „religia” $i$,przekonania” - zdaniem Komitetu - maja być rozumiane szeroko. Art. 18 w zastosowaniu swym nie ogranicza się do charakterystycznych cech instytucjonalnych czy do praktyk analogicznych do praktyk religii tradycyjnych. Komitet - jak skonstatowano - spoglada zatem z zainteresowaniem na każda tendencję krzywdzacej dyskryminacji jakiejś religii czy przekonań z jakichkolwiek powodów, włączajac $w$ to fakt, że sa one nowo uksztaltowanymi, czy też, że reprezentuja one mniejszości religijne, które moga podlegać wrogiemu stosunkowi ze strony dominujacej wspólnoty religijnej ${ }^{27}$.

${ }^{26}$ Art. 18 MPPOiP stanowi:

1. Każdy ma prawo do wolności myśli, sumienia i wyznania. Prawo to obejmuje wolność posiadania lub przyjmowania wyznania lub przekonań wedtug własnego wyboru oraz do uzewnętrzniania indywidualnie czy wspólnie z innymi, publicznie lub prywatnie, swej religii lub przekonań przez uprawianie kultu, uczestniczenie $w$ obrzędach, praktykowanie i nauczanie.

2. Nikt nie może podlegać przymusowi, który stanowitby zamach na jego wolność posiadania lub przyjmowania wyznania albo przekonań wedtug własnego wyboru.

3. Wolność uzewnętrzniania wyznania lub przekonań może podlegać jedynie takim ograniczeniom, które sa przewidziane przez ustawę i są konieczne dla ochrony bezpieczeństwa publicznego, porzadku, zdrowia lub moralności publicznej albo podstawowych praw $i$ wolności innych osób.

4. Państwa Strony niniejszego Paktu zobowiąuja się do poszanowania wolności rodziców lub, w odpowiednich przypadkach, opiekunów prawnych do zapewnienia swym dzieciom wychowania religijnego i moralnego zgodnie z własnymi przekonaniami.

Oficjalna wykładnia art. 18 MPPOiP została ustalona przez Komitet Praw Człowieka ONZ w $1993 \mathrm{r}$.

${ }^{27}$ Zob. Uwagi Ogólne Komitetu Praw Człowieka ONZ nr 22 (28) dotyczące art. 18, przyjęte 20 lipca 1993 r. - Wolność religii. Wybór materiałów. Dokumenty. Orzecznictwo, tłum. i oprac. Tadeusz Jasudowicz (Toruń: „Dom Organizatora” TNOiK, 2001), 70. 
Doniosłość prawa do wolności myśli, sumienia i religii (wyznania) w systemie ochrony praw człowieka ONZ znalazła swój wyraz w Deklaracji ONZ z 1981 r. w sprawie wyeliminowania wszelkich form dyskryminacji opartych na religii lub przekonaniach. Prace nad omawianym aktem, na forum ONZ, trwały ok. dwudziestu pięciu lat. Deklaracja może być traktowana jako swoisty akt wykonawczy do art. 18 MPPOiP. Szeroko definiuje ona dyskryminację ze względu na religię lub przekonania i zdecydowanie jej zakazuje. Należy mocno podkreślić, że Deklaracja zawiera także pionierskie, pewne gwarancje dla dzieci w zakresie ich niedyskryminacji ze względu na religię lub przekonania, a także w sferze wolności myśli sumienia i wyznania (zob. art. 5 ust. 2-5). Państwa-sygnatariusze Deklaracji zobowiązały się do podjęcia skutecznych środków dla zapobiegania i eliminowania dyskryminacji na podstawie religii lub przekonań w uznaniu, urzeczywistnianiu i korzystaniu z praw człowieka i podstawowych wolności we wszystkich dziedzinach życia obywatelskiego, gospodarczego, politycznego, społecznego i kulturalnego (art. 4 ust. 1). Ponadto państwa zadeklarowały podjęcie wszelkich wysiłków na rzecz wydania, bądź tam, gdzie zachodzi taka potrzeba - uchylenia ustawodawstwa, celem zakazania jakiejkolwiek tego rodzaju dyskryminacji, jak też na rzecz podjęcia wszelkich właściwych środków służących zwalczaniu nietolerancji na podstawie religii bądź innych przekonań (art. 4 ust. 2). Pragnąc dodatkowo wzmocnić ochronny charakter Deklaracji, państwa-sygnatariusze uznały, że prawa i wolności ustalone w Deklaracji będą przyznawane w ustawodawstwie krajowym w taki sposób, by każda osoba dysponowała możliwością korzystania z nich w praktyce.

Treść Deklaracji ONZ z 1981 r. wyraźnie wykracza poza problematykę dyskryminacji ze względu na religię lub przekonania. Równorzędnym przedmiotem regulacji stała się wolność myśli, sumienia, religii lub przekonań (zob. art. 1 i 4). Deklaracja zawiera m.in. szczegółowy (przykładowy) katalog uprawnień, składających się na omawianą wolność. Są to przede wszystkim uprawnienia w praktyce realizowane w ramach i w oparciu o związki wyznaniowe ${ }^{28}$. Słabością Dekla-

${ }^{28}$ Według art. 4 Deklaracji ONZ z 1981 r. prawo do wolności myśli, sumienia, religii lub przekonań będzie obejmowało, między innymi, następujące wolności: 
racji z 1981 r. jest to, że nie ma ona charakteru formalnie wiążącego państwa-strony. Nie jest umową międzynarodową, a więc trudno twierdzić, w przeciwieństwie do Powszechnej Deklaracji Praw Człowieka, że stanowi ona element zwyczajów międzynarodowych. Niewątpliwie jej szczegółowe postanowienia mogą stanowić inspirację dla Komitetu Praw Człowieka ONZ przy ocenie przestrzegania przez poszczególne państwa-strony norm zawartych m.in. w MPPOiP. Naruszanie postanowień Deklaracji z 1981 r. stanowi potencjalną i uzasadnioną przesłankę do politycznych nacisków wobec państwa, które, mimo że jest jej sygnatariuszem, nie zapewnia respektowania jej postanowień.

Szczególną, wiążącą prawnie Polskę, uniwersalną umową międzynarodową, chroniącą m.in. przed dyskryminacją opartą na religii lub przekonaniach wrażliwą kategorię osób, tzn. dzieci ${ }^{29}$ jest Konwencja Praw Dziecka ONZ z 1989 r. (Dz. U. z 1991 r. Nr 120, poz. 526 z późn. zm.). Gwarancje niedyskryminacji dzieci ze względu na religię lub inne przekonania światopoglądowe zostały zawarte w art. 2 ust. 1 Konwencji. Przepis ten przypomina art. 2 Powszechnej Deklaracji Praw Człowieka oraz art. 2 MPPOiP ONZ. Państwa-strony zobowiązały się,

a) Modlitwy i zgromadzania się dla potrzeb religii lub przekonań, jak też ustanawiania i utrzymywania placówek temu celowi służących;

b) Ustanawiania i utrzymywania stosownych instytucji charytatywnych lub humanitarnych;

c) Produkowania, nabywania i wykorzystywania, w stosownym zakresie, koniecznych artykułów i materiałów związanych z rytuałem albo obyczajami danej religii lub przekonań;

d) Pisania, wydawania i rozpowszechniania odpowiednich publikacji w tych dziedzinach;

e) Nauczania religii lub przekonań w odpowiednich dla tego celu placówkach;

f) Ubiegania się o i uzyskiwania dobrowolnych wkładów finansowych bądź innych od jednostek i instytucji;

g) Szkolenia, wskazywania, doboru lub wyznaczania drogą sukcesji odpowiednich przewodników, stosownie do wymagań i standardów jakiejkolwiek religii lub przekonań;

h) Przestrzegania dni odpoczynku oraz obchodzenia świąt i ceremonii zgodnie z przepisami czyjejś religii lub przekonań;

i) Ustanawiania i utrzymywania kontaktów z jednostkami i wspólnotami w dziedzinie religii lub przekonań na poziomie krajowym i międzynarodowym.

${ }^{29}$ Zgodnie z art. 1 Konwencji „dziecko” oznacza każdą istotę ludzką w wieku poniżej osiemnastu lat, chyba że zgodnie z prawem odnoszącym się do dziecka uzyska ono wcześniej pełnoletność. Ustawa z dnia 6 stycznia 2000 r. o Rzeczniku Praw Dziecka (Dz. U. z 2000 r. Nr 6, poz. 69 z późn. zm.) za dziecko uznaje każdą istotę ludzką od poczęcia aż do osiągnięcia pełnoletności (tj. co do zasady 18 lat). 
że w granicach swojej jurysdykcji będą respektowały i gwarantowały prawa zawarte w Konwencji wobec każdego dziecka, bez jakiejkolwiek dyskryminacji, niezależnie od rasy, koloru skóry, płci, języka, religii, poglądów politycznych, statusu majątkowego, niepełnosprawności, cenzusu urodzenia lub jakiegokolwiek innego tego dziecka albo jego rodziców bądź opiekuna prawnego. Państwa-strony zobligowały się ponadto do podejmowania właściwych kroków dla zapewnienia ochrony dziecka przed wszelkimi formami dyskryminacji lub karania ze względu na status prawny, działalność, wyrażane poglądy lub przekonania religijne rodziców dziecka, opiekunów prawnych lub członków rodziny (art. 2 ust. 2). Za trafne i realistyczne należy uznać wymienienie wśród przesłanek niedopuszczalnej dyskryminacji dzieci, kryterium wyrażanych poglądów i przekonań religijnych rodziców dziecka (opiekunów prawnych). Dziecko nie jest bowiem całkowicie niezależnym podmiotem $\mathrm{w}$ dziedzinie przekonań w sprawach religijnych. Jego światopogląd jest kształtowany przede wszystkim przez rodziców. Można powiedzieć w uproszczeniu, że światopogląd dziecka to niejako przedłużenie (refleks) światopoglądu rodziców. Z reguły też dziecko nie jest autonomiczne pod względem społecznym i ekonomicznym, pozostając z rodzicami we wspólnocie domowej. W praktyce urzeczywistnianie przez dziecko szeregu wolności i praw, realizacja własnych aspiracji, odbywają się w ramach rodziny kierowanej przez rodziców lub w oparciu o taką rodzinę.

Konwencja nie wymienia poza religią żadnych innych rodzajów przekonań światopoglądowych czy bezwyznaniowości, jako niedopuszczalnych kryteriów dyskryminacji dzieci w sferze należnych im wolności i praw. Można jednak zakaz dyskryminacji ze względu na kryterium światopoglądu niereligijnego wyprowadzić z terminu ,jakiejkolwiek innej przyczyny", lub też przyjmując rozszerzającą interpretację terminu „religia”, utrwaloną przez lata działalności Komitetu Praw Człowieka ONZ. 


\section{EUROPEJSKIE STANDARDY PRZECIWDZIAŁANIA DYSKRYMINACJI}

ZE WZGLĘDU NA RELIGIĘ (WYZNANIE) LUB ŚWIATOPOGLĄD (BEZWYZNANIOWOŚĆ)

Konwencja o Ochronie Praw Człowieka i Podstawowych Wolności z 1950 r zakaz dyskryminacji ustanawia w art. 14, stanowiąc, iż korzystanie z praw $i$ wolności wymienionych $w$ niniejszej konwencji powinno być zapewnione bez dyskryminacji wynikajacej z takich powodów, jak płeć, rasa, kolor skóry, język, religia, przekonania polityczne i inne, pochodzenie narodowe lub społeczne, przynależność do mniejszości narodowej, majątek, urodzenie bądź z jakichkolwiek innych przyczyn ${ }^{30}$. Zakaz dyskryminacji przewidziany przez EKPCz dotyczy zatem nie samego faktu dyskryminacji w danym państwie, które Konwencję ratyfikowało i poddało się jurysdykcji Europejskiego Trybunału Praw Człowieka (ETPCz), ale dyskryminacji w korzystaniu z wolności i praw „materialnych” gwarantowanych przez analizowany akt. Z treści art. 14 jednoznacznie wynika, że w omawianym zakresie zabroniona jest dyskryminacja ze względu na religię, ale także ze względu na inne przekonania w sprawach religijnych. W szczególności art. 14 EKPCz chroni przed dyskryminacją w zakresie korzystania $\mathrm{z}$ gwarantowanej $\mathrm{w}$ art. 9 wolności myśli, sumienia i wyznania, czy wolności wyrażania opinii (art. 10). Treść owych wolności w praktyce określa przede wszystkim orzecznictwo ETPCz. Należy podkreślić, iż w świetle orzecznictwa organów strasburskich stwierdzenie naruszenia „materialnych” wolności i praw gwarantowanych przez EKPCz nie jest warunkiem koniecznym do orzeczenia naruszenia art. 14 Konwencji. Zarazem orzecznictwo organów strasburskich wskazuje, że Konwencja nie zapewnia równej ochrony wolności wyrażania światopoglądu niereligijnego w wymiarze kolektywnym, w porównaniu z realizowaną przez związki wyznaniowe kolektywną wolnością wyznania religii. Ochrona kolektywnej wolności uzewnętrzniania religii, realizowanej poprzez związki wyznaniowe, dokonuje się na podstawie przepisu art. 9 ust. EKPCz, który obliguje Trybunał Praw Człowieka do ochrony

${ }^{30}$ Zob. http://bip.mkidn.gov.pl/media/download_gallery/20141028Konwencja_wraz_z protokolem_11.pdf [dostęp: 3.07.2015]. 
szeroko rozumianej autonomii związków wyznaniowych. Natomiast w przypadku konieczności zapewnienia ochrony kolektywnej wolności uzewnętrzniania światopoglądu niereligijnego w wymiarze organizacyjnym tzw. organizacjom laickim, orzecznictwo wskazuje, że Trybunał nie zapewnia tak daleko idącej, równej, ochrony. Organizacje laickie w praktyce mogą poszukiwać ochrony wolności wyznawania światopoglądu niereligijnego, powołując się na art. $11 \mathrm{EKPCz}$ (wolność zrzeszeń) ${ }^{31}$. Można więc mówić o pewnej dyskryminacji (nierównym traktowaniu) przez ETPCz osób areligijnych w zakresie ochrony ich wolności do kolektywnego uzewnętrzniania światopoglądu. We współczesnej Europie pomimo daleko posuniętych procesów laicyzacyjnych, postępującej prywatyzacji przekonań w sprawach religijnych oraz pluralizacji konfesyjnej społeczeństw, wciąż światopoglądowi religijnemu, a zwłaszcza tradycyjnym religiom monoteistycznym, gwarantowana jest w zdecydowanej większości państw oraz przez organa Rady Europy praktyczna wyższość, w szczególności uprzywilejowanie, w ochronie prawnej w porównaniu $\mathrm{z}$ innymi formami światopoglądu.

Ochrona przed dyskryminacją, w ramach porządku prawnego poszczególnych państw, uległa zasadniczemu rozszerzeniu na podstawie Protokołu 12 do EKPCz z 2000 r. Akt ten m.in. zakazuje dyskryminacji ze względu na przekonania w sprawach religijnych w wewnątrzkrajowych systemach prawnych. Art. 1 Protokołu stanowi bowiem, że korzystanie z każdego prawa przewidzianego $w$ prawie powinno być zapewnione bez dyskryminacji wynikającej z takich powodów, jak płeć, rasa, kolor skóry, język, religia, przekonania polityczne lub inne, pochodzenie narodowe lub spoleczne, przynależność do mniejszości narodowej, majątek, urodzenie lub z jakichkolwiek innych przyczyn (art. 1 ust. $1)^{32}$. Protokół 12 zobowiązuje też państwa do zapewnienia niedyskryminacji nie tylko w wymiarze formalno-prawnym, ale także w praktyce działania władz poszczególnych państw w szerokim tego słowa rozumieniu. Protokół gwarantuje bowiem w art. 1 ust. 2, że nikt nie

${ }^{31}$ Zob. Konwencja o Ochronie Praw Człowieka i Podstawowych Wolności. Komentarz do artykułów 1-18, tom I, red. Lech Garlicki (Warszawa: C.H.Beck, 2010), 577.

${ }^{32}$ Zob. http://www.ptpa.org.pl/public/files/akty_prawne/Protokol_nr_12_do_KwSLWFDK. pdf [dostęp: 3.07.2015]. 
może być dyskryminowany przez jakiekolwiek władze publiczne z któregokolwiek $z$ powodów wymienionych $w$ ust. $1^{33}$. Niestety, terytorialny zakres ochrony przed dyskryminacją, gwarantowany przez Protokół 12 do EKPCz, jest ograniczony. Akt ten ratyfikowało do chwili obecnej zaledwie 18 państw członkowskich Rady Europy. Nie ma wśród nich Polski, która, jako jedno z nielicznych państw członkowskich Rady Europy, nawet nie podpisała rzeczonego Protokołu ${ }^{34}$.

\section{UNIA EUROPEJSKA A ZAKAZ DYSKRYMINACJI ZE WZGLĘDU}

NA RELIGIĘ LUB PRZEKONANIA.

Zwalczanie dyskryminacji należy do głównych celów Unii Europejskiej (UE). Zgodnie z art. 3 ust. 3 Traktatu o Unii Europejskiej (TUE), UE [z]walcza wykluczenie społeczne $i$ dyskryminacje oraz wspiera sprawiedliwość społeczna $i$ ochrone socjalna, równość kobiet $i$ mężczyzn, solidarność między pokoleniami $i$ ochronę praw dziecka. Zwalczanie dyskryminacji to jedno z zasadniczych zadań działania UE. Przy określaniu i realizacji swoich polityk $i$ działań Unia, jak stanowi art. 10 Traktatu o funkcjonowaniu Unii Europejskiej (TfUE), dązy do zwalczania wszelkiej dyskryminacji ze względu na płeć, rasę lub pochodzenie etniczne, religię lub światopoglad, niepetnosprawność, wiek lub orientację seksualna, zaś w art. 9 TUE czytamy, że [w]e wszystkich swoich działaniach Unia przestrzega zasady równości swoich obywateli, którzy sa traktowani z jednakowa uwaga przez jej instytucje, organy $i$ jednostki organizacyjne. Konkludując, należy uznać, że UE opiera się na paradygmacie niedyskryminacji, w szczególności ze względu na religię (wyznanie) lub światopogląd (bezwyznaniowość).

Należy jednak podkreślić, że w myśl art. 3 ust. 4 TUE Unia dąży do osiągnięcia swoich celów właściwymi środkami, odpowiednio do

33 Tamże.

${ }^{34}$ Według stanu na dzień 3 lipca 2015 r. są to: Albania, Andora, Armenia, Bośnia i Hercegowina, Chorwacja, Cypr, Finlandia, Gruzja, Hiszpania, Luksemburg, Holandia, Czarnogóra, Rumunia, San Marino, Serbia, Słowenia, Macedonia i Ukraina - zob. http://conventions.coe. int/Treaty/Commun/ChercheSig.asp?NT=177\&CM=\&DF=\&CL=ENG [dostęp: 3.07.2015]. 
kompetencji przyznanych jej $\mathrm{w}$ traktatach założycielskich. Zgodnie $\mathrm{z}$ art. 4 ust. $1 \mathrm{i}$ art. 5 TUE wszelkie kompetencje nieprzyznane Unii w Traktatach należą do państw członkowskich. Żadnych kompetencji UE, także w dziedzinie zwalczania dyskryminacji, nie można domniemywać, bowiem według art. 5 ust. 1 TUE granice kompetencji Unii wyznacza zasada przyznania. Wykonywanie tych kompetencji podlega zasadom pomocniczości i proporcjonalności. Zgodnie z zasadą przyznania, Unia działa wyłącznie w granicach kompetencji, przyznanych jej przez Państwa Członkowskie w Traktatach, w celu osiągnięcia określonych w nich celów. Wszelkie kompetencje, nieprzyznane Unii w traktatach założycielskich, należą do państw członkowskich (art. 5 ust. 2). Zgodnie z zasadą pomocniczości, w dziedzinach, które nie należą do jej wyłącznej kompetencji, Unia podejmuje działania tylko wówczas i tylko w takim zakresie, $w$ jakim cele zamierzonego działania nie mogą zostać osiągnięte w sposób wystarczający przez państwa członkowskie, zarówno na poziomie centralnym, jak i regionalnym oraz lokalnym, i jeśli - ze względu na rozmiary lub skutki proponowanego działania - możliwe jest lepsze ich osiągnięcie na poziomie Unii (art. 5 ust. 3). Natomiast, zgodnie z zasadą proporcjonalności, zakres i forma działania Unii nie wykraczają poza to, co jest konieczne do osiągnięcia celów Traktatów (art. 5 ust. 4).

Zwalczanie dyskryminacji przez UE, zwłaszcza ze względu na przekonania w sprawach religijnych, znajduje dodatkowe wzmacnianie w postanowieniach Karty Praw Podstawowych UE. Zgodnie z art. 6 ust. 1 TUE Unia uznaje prawa, wolności i zasady określone w Karcie Praw Podstawowych Unii Europejskiej z 7 grudnia 2000 roku, w brzmieniu dostosowanym 12 grudnia 2007 roku w Strasburgu, która ma taka sama moc prawna jak Traktaty ${ }^{35}$. Art. 21 ust. 1 Karty, zawarty w Rozdziale 3 zatytułowanym „Równość”, zakazuje dyskryminacji w szerokim i szczegółowym zakresie, stanowiąc, że [z]akazana jest wszelka dyskryminacja ze względu na płeć, rasę, kolor skóry, pochodzenie etniczne lub społeczne, cechy genetyczne, język, religię lub światopoglad, opinie polityczne lub wszelkie inne, przynależność do mniejszości

${ }^{35}$ Zob. http://oide.sejm.gov.pl/oide/index.php?option=com_content\&view=article\&id= 14803\&Itemid=945 [dostęp: 16.07.2015]. 
narodowej, majątek, urodzenie, niepetnosprawność, wiek lub orientacje seksualna ${ }^{36}$. W Karcie Praw Podstawowych wyraźne jest także podejście pozytywne. Zgodnie z art. 20 wszyscy są równi wobec prawa, zaś UE, jak głosi art. 22 Karty, szanuje zróżnicowanie kulturalne, religijne i językowe. Należy przy tym mocno podkreślić, że gwarancje dotyczące wolności i praw, o których mowa w Karcie, dotyczą bezpośrednio UE jako organizacji, a nie państw członkowskich, czy też ich społeczeństw. Zgodnie z art. 51 Karty, jej postanowienia mają zastosowanie do instytucji i organów Unii, z właściwym uwzględnieniem zasady pomocniczości, oraz do państw członkowskich w zakresie, w jakim stosują one prawo Unii. Państwa członkowskie UE szanują prawa, przestrzegają zasad i popierają ich stosowanie zgodnie ze swymi kompetencjami. Sama Karta nie ustanawia żadnej nowej kompetencji ani zadania dla Wspólnoty lub Unii. Nie zmienia też kompetencji i zadań określonych w traktatach założycielskich.

Należy zauważyć, że w świetle TUE gwarancje niedyskryminacji na szczeblu prawa unijnego łączą się, na razie dość luźno, z gwarancjami przewidzianymi przez EKPCz. Jak stanowi art. 6 ust. 3 TUE, [p] rawa podstawowe, zagwarantowane w Europejskiej Konwencji o Ochronie Praw Człowieka i Podstawowych Wolności, [czyli również przewidziany w art. 14 Konwencji zakaz dyskryminacji ze względu na religię lub światopogląd], oraz wynikające z tradycji konstytucyjnych wspólnych Państwom Członkowskim, stanowia część prawa Unii jako zasady ogólne prawa ${ }^{37}$. W TUE zapowiedziano także przystąpienie Unii do EKPCz (art. 6 ust. 2). Prowadzone w tej sprawie negocjacje dotychczas nie przyniosły sukcesu.

Należy podkreślić, że UE jako organizacja i podmiot prawa międzynarodowego, jest neutralna światopoglądowo, zaś zasady niedyskryminacji i równego traktowania urzeczywistnia konsekwentnie także wobec związków wyznaniowych (kościołów) i organizacji laickich. W art. 17 TfUE czytamy:

${ }^{36}$ Zob. http://oide.sejm.gov.pl/oide/?option=com_content\&view=article\&id=14428\&It emid=422 [dostęp: 16.07.2015].

${ }^{37}$ Zob. http://oide.sejm.gov.pl/oide/index.php?option=com_content\&view=article\&id= 14803\&Itemid=945 [dostęp: 16.07.2015]. 
1. Unia szanuje status przyznany na mocy prawa krajowego kościołom i stowarzyszeniom lub wspólnotom religijnym w Państwach Członkowskich i nie narusza tego statusu.

2. Unia szanuje na równi status organizacji światopoglądowych i niewyznaniowych przyznany im na mocy prawa krajowego.

3. Uznając tożsamość i szczególny wkład tych kościołów i organizacji, Unia prowadzi z nimi otwarty, przejrzysty i regularny dialog ${ }^{38}$.

Powyższe ujęcie istotnie odróżnia prawo pierwotne UE od systemów prawnych większości państw członkowskich, które wyraźnie preferują związki wyznaniowe, szczególnie związki „tradycyjne”. Różni się ono także od wzorca ochrony kolektywnej wolności uzewnętrzniania przekonań w sprawach religijnych, wypracowanego w orzecznictwie Trybunału Praw Człowieka, organu Rady Europy.

Do urzeczywistnienia zasady niedyskryminacji jednostki ze względu na wyznawaną religię, wyznanie lub światopogląd (bezwyznaniowość) dąży także UE w swoim prawie wtórnym. Jest to czytelne zwłaszcza w zakresie norm określających standardy zatrudnienia i pracy. Dyrektywa $\mathrm{Nr}$ 2000/78/WE z 27 listopada 2000 r., ustanawiająca ramy równego traktowania w zatrudnieniu ${ }^{39}$, zakazuje wyraźnie dyskryminacji, w szczególności opartej na religii lub przekonaniach. Znamienne, że na potrzeby rzeczonego aktu zakaz dyskryminacji zostaje utożsamiony również $\mathrm{z}$ równym traktowaniem bez względu na religię lub przekonania (zob. art. $1 \mathrm{w}$ związku z art. 2 ust. 1). Prawodawca unijny użył terminologii wyraźnie zbieżnej z terminologią zastosowaną w Deklaracji ONZ z 1981 r. W Dyrektywie sformułowano także definicje legalne dyskryminacji bezpośredniej i dyskryminacji pośredniej. Zgodnie z wykładnią Dyrektywy, dyskryminacja bezpośrednia występuje w przypadku, gdy osobę traktuje się, traktowano lub traktowano by mniej przychylnie, niż traktuje się, traktowano lub traktowano by inną osobę w porównywalnej sytuacji, z jakiejkolwiek przyczyny wymienionej $\mathrm{w}$ art. 1, czyli również ze względu na religię lub przekonania

${ }^{38}$ Polskie oficjalne thumaczenie art. 17 ust. 2 TfUE jest znamiennie nieprecyzyjne. Słowo: également przetłumaczono, nie tak jak to jest w języku francuskim, na słowa na równi ale na słowo: również, co istotnie zmienia wymowę ar. 17 ust. 2 TfUE.

${ }^{39}$ Dz. Urz. UE L 303/2000, Dz. Urz. UE-sp.05-4-79. 
(art. 2 ust. 2 lit. a). Natomiast dyskryminacja pośrednia ma miejsce w przypadku, gdy przepis, kryterium lub pozornie neutralna praktyka może doprowadzić do szczególnie niekorzystnej sytuacji dla osób danej religii lub przekonań, niepełnosprawności, wieku, orientacji seksualnej i w stosunku do wszystkich innych osób, chyba że przepis, kryterium lub praktyka są obiektywnie uzasadnione zgodnym z prawem celem, a środki mające służyć osiągnięciu tego celu są właściwe i konieczne, lub jeżeli - w przypadku osób w określony sposób niepełnosprawnych - pracodawca lub każda osoba, do której odnosi się niniejsza dyrektywa, jest zobowiązany, na mocy przepisów krajowych, podejmować właściwe środki zgodnie z zasadami określonymi w art. 5 Dyrektywy, w celu zlikwidowania niedogodności spowodowanych tym przepisem, kryterium lub praktyką (art. 2 ust. 2 lit. b.).

Należy zaznaczyć, że w świetle Dyrektywy za formę dyskryminacji zostało uznane także molestowanie, jeżeli to niepożądane zachowanie ma związek z religią lub przekonaniami, a jego celem lub skutkiem jest naruszenie godności człowieka i stworzenie onieśmielającej, wrogiej, poniżającej, upokarzającej lub uwłaczającej atmosfery (art. 2 ust. 3).

Zgodnie $\mathrm{z}$ art. 3 Dyrektywy, ma on zastosowanie $\mathrm{w}$ granicach kompetencji UE do wszystkich osób, zarówno sektora publicznego jak i prywatnego, włącznie z instytucjami publicznymi, w odniesieniu do:

a) warunków dostępu do zatrudnienia lub pracy na własny rachunek, w tym również do kryteriów selekcji i warunków rekrutacji, niezależnie od dziedziny działalności i na wszystkich szczeblach hierarchii zawodowej oraz w odniesieniu do awansu zawodowego;

b) dostępu do wszystkich rodzajów i szczebli poradnictwa zawodowego, kształcenia zawodowego, doskonalenia i przekwalifikowania zawodowego, łącznie ze zdobywaniem praktycznych doświadczeń;

c) warunków zatrudnienia i pracy, łącznie z warunkami zwalniania i wynagradzania;

d) członkostwa i działania w organizacjach pracowników lub pracodawców bądź jakiejkolwiek organizacji, której członkowie wykonują określony zawód, łącznie z korzyściami, jakie dają tego typu organizacje.

Państwom członkowskim pozostawiono pewien zakres swobody, wszakże tylko w odniesieniu do sytuacji niestanowiącej zakazanej 
dyskryminacji. Zgodnie z art. 4 ust. 1 Dyrektywy, państwa członkowskie mogą uznać, że odmienne traktowanie ze względu na cechy związane $\mathrm{z}$ jedną $\mathrm{z}$ przyczyn wymienionych $\mathrm{w}$ art. 1, nie stanowi dyskryminacji w przypadku, gdy w związku z rodzajem działalności zawodowej lub warunkami jej wykonywania, dane cechy są istotnym i determinującym wymogiem zawodowym, pod warunkiem wszakże, że cel jest zgodny z prawem, a wymóg jest proporcjonalny. Ponadto państwa członkowskie mogą utrzymać w mocy swoje ustawodawstwo krajowe, które obowiązywało w dniu przyjęcia Dyrektywy. Mogą też przewidzieć w przyszłym ustawodawstwie - uwzględniając praktykę krajową istniejącą $\mathrm{w}$ dniu przyjęcia omawianego aktu - przepisy, na mocy których, w przypadku działalności zawodowej kościołów, innych organizacji publicznych bądź prywatnych, których etyka wywodzi się z religii lub z przekonań niereligijnych, możliwe jest odmienne traktowanie ze względu na religię lub przekonania i nie stanowi to dyskryminacji w przypadku, gdy ze względu na charakter działalności lub kontekst, w którym jest prowadzona, religia lub przekonania areligijne stanowią podstawowy, zgodny z prawem i uzasadniony wymóg zawodowy, uwzględniający etykę danej organizacji. Odmienne traktowanie powinno być realizowane z poszanowaniem zasad i postanowień konstytucyjnych państw członkowskich, a także zasad ogólnych prawa wspólnotowego. Nie powinno być ono usprawiedliwieniem dla dyskryminacji, u podstaw której leżą inne przyczyny. Zatem, co podkreśla prawodawca unijny, pod warunkiem że jej przepisy sa przestrzegane, [...] dyrektywa nie narusza więc prawa kościołów i innych organizacji publicznych lub prywatnych, których etyka opiera się na religii lub przekonaniach, działajacych zgodnie z krajowymi przepisami konstytucyjnymi i ustawodawczymi, do wymagania od osób pracujacych dla nich działania $w$ dobrej wierze i lojalności wobec etyki organizacji (art. 4 ust. 2).

Ponadto Dyrektywa nałożyła na państwa członkowskie obowiązek stworzenia gwarancji proceduralnych niedyskryminacji w dziedzinie zatrudnienia, m.in. ze względu na religię i przekonania. Stwierdzono w Dyrektywie jednoznacznie, że państwa członkowskie zapewnia, aby procedury sadowe i/lub administracyjne oraz, w przypadku gdy uznaja to za właściwe, procedury pojednawcze, których celem jest doprowa- 
dzenie do stosowania zobowiazań wynikajacych z niniejszej dyrektywy, byty dostępne dla wszystkich osób, które uważaja się za pokrzywdzone w zwiazku z naruszeniem wobec nich zasady równego traktowania, nawet po zakończeniu zwiazku, w którym przypuszczalnie miała miejsce dyskryminacja (art. 9 ust. 1). Na państwa członkowskie został także nałożony obowiązek zapewnienia, aby stowarzyszenia, organizacje lub osoby prawne, które maja, zgodnie z przewidzianymi prawem krajowym kryteriami, uzasadniony interes $w$ zapewnieniu aby przestrzegane byly postanowienia niniejszej dyrektywy, mogły wszczynać, na rzecz osoby występujacej z powództwem lub ja wspierajac, za jej zgoda, postępowania sadowe i/lub procedury administracyjne przewidziane $w$ celu spowodowania stosowania niniejszej dyrektywy (art. 9 ust. 2).

Prawodawca unijny realistycznie zwrócił także uwagę na konieczność zapewnienia szczegółowych gwarancji proceduralnych dla „ofiary” niedopuszczalnej dyskryminacji, jako strony słabszej w stosunkach faktycznych i prawnych, poprzez przerzucenie ciężaru dowodu na pozwanego w postępowaniu sądowym lub innym właściwym. Przepisem art. 10 ust. 1 Dyrektywy państwa członkowskie zostały zobligowane, aby zgodnie $z$ krajowymi systemami sądowymi, zapewniły niezbędne środki, aby to strona pozwana musiała udowodnić, że nie wystąiło pogwałcenie zasady równego traktowania w przypadku, gdy osoby uważające się za pokrzywdzone, przed sądem lub innym właściwym organem ustalą fakty, nasuwające przypuszczenie o zaistnieniu bezpośredniej czy pośredniej dyskryminacji. Nie może to jednak prowadzić do zwolnienia od działań z urzędu kompetentnych organów państwowych, bowiem zastrzeżono w Dyrektywie, że państwa członkowskie nie mogą stosować przepisu ust. 1 do procedur sądowych, w których ustalenie okoliczności faktycznych sprawy należy do sądu lub właściwego organu (art. 10 ust. 5). 
IV. ZAKAZ DYSKRYMINACJI ZE WZGLĘDU NA RELIGIĘ LUB ŚWIATOPOGLĄD W USTAWODAWSTWIE KRAJOWYM

\section{USTAWA O GWARANCJACH WOLNOŚCI SUMIENIA I WYZNANIA}

W ustawodawstwie krajowym zakaz dyskryminacji ze względu na religię (wyznanie) lub światopogląd (bezwyznaniowość) wynika przede wszystkim z postanowień ustawy z dnia 17 maja 1989 r. o gwarancjach wolności sumienia i wyznania. Ustawa ta, w zamyśle jej historycznych twórców, miała stanowić akt wykonawczy do bardzo ogólnych postanowień wyznaniowych Konstytucji Polskiej Rzeczypospolitej Ludowej z 22 lipca 1952 r. (zob. art. 81 i art. 82 wg stanu z 29 grudnia 1989 r.) $)^{40}$. Szereg postanowień rzeczonej ustawy, szczególnie tych, które zawarte były w dziale I ma charakter fundamentalny. Niektóre z nich mogłyby z powodzeniem znaleźć się w ustawie zasadniczej, a już na pewno w ustawie organicznej, o ile polski system prawny przewidywałby taką kategorię aktów prawa powszechnie obowiązującego. Postanowienia ustawy z 17 maja 1989 r. zmieniały praktykę Polski Ludowej, charakteryzującą się dyskryminacją osób wierzących przez aparat partyjno-państwowy w sferach życia: politycznego, społecznego, gospodarczego, a także zawodowego. Praktykę ową znamionowało, jeśli nie zwalczanie związków wyznaniowych, to co najmniej ograniczanie zakresu ich działalności, oraz ich instrumentalne traktowanie przez władze wszystkich szczebli, zgodnie z zasadą ,dziel i rządź”. W okresie Polski Ludowej, generalnie rzecz ujmując, przy odrzuceniu zasady neutralności światopoglądowej państwa, charakter oficjalnego światopoglądu zyskał światopogląd materialistyczny (ateistyczny). Ustawy wyznaniowe z 17 maja 1989 r. ${ }^{41}$, a przede wszystkim ustawa o gwarancjach wolności sumienia i wyznania, stały się zasadniczą reorientacją ustawodawstwa w sprawach wyznaniowych. Problem polegał przede

${ }^{40}$ Dz. U. z 1976 r. Nr 7, poz. 36 z późn. zm.

${ }^{41}$ Były to: ustawa z 17 maja 1989 r. o stosunku Państwa do Kościoła Katolickiego w Polskiej Rzeczypospolitej Ludowej (Dz. U. Nr 29, poz. 154), ustawa z 17 maja 1989 r. o gwarancjach wolności sumienia i wyznania (Dz. U. Nr 29, poz. 155) oraz ustawa z 17 maja 1989 r. o ubezpieczeniu społecznym duchownych (Dz. U. Nr 29, poz. 156). 
wszystkim na tym, iż ustanawiając ustawy wyznaniowe w 1989 r., zakładano ich obowiązywanie w państwie autorytarnym, rządzonym nadal przez Polską Zjednoczoną Partię Robotniczą, a tymczasem przyszło je stosować w państwie demokratycznym, od 1989 r. szybko nabierającym szeregu cech wyznaniowego państwa katolickiego. Ważną okolicznością pozwalającą zrozumieć treść i cele ustawy o gwarancjach wolności sumienia i wyznania jest także to, iż projekt ustawy był przygotowany w latach 1987-1989 w wyniku rozmów przedstawicieli ówczesnych władz oraz reprezentantów związków wyznaniowych, przede wszystkim kościołów skupionych w Polskiej Radzie Ekumenicznej ${ }^{42}$.

Ustawa o gwarancjach wolności sumienia i wyznania posiada zdecydowanie liberalną wymowę ${ }^{43}$. Stanowi udaną próbę uzgodnienia polskiego ustawodawstwa wyznaniowego ze standardami wynikającymi z międzynarodowych aktów prawnych, m.in. z Deklaracji ONZ z 1981 r., chroniących wolność w sprawach religijnych. Świadczy o tym preambuła ustawy, stanowiąca m.in. [...] kierujac się zasadami zawartymi w Powszechnej Deklaracji Praw Człowieka, Międzynarodowym Pakcie Praw Obywatelskich i Politycznych, Akcie Końcowym Konferencji Bezpieczeństwa i Współpracy w Europie oraz Deklaracji Organizacji Narodów Zjednoczonych o wyeliminowaniu wszelkich form nietolerancji $i$ dyskryminacji z powodów religijnych lub przekonań [...]. Wyraźnym celem ustawodawcy było wyeliminowanie dyskryminacji obywateli, jak również cudzoziemców i bezpaństwowców w życiu społecznym i publicznym ze względu na przekonania w sprawach religijnych. W ustawowej arendzie stwierdza się bowiem: umacniajac warunki do czynnego i równoprawnego uczestnictwa obywateli w życiu publicznym i społecznym, bez względu na ich stosunek do religii [...]. Treści preambuły stanowią czytelne dyrektywy interpretacyjne dla przepisów części normatywnej analizowanej ustawy.

${ }^{42}$ Szerzej na temat historii prac nad ustawami wyznaniowymi z dnia 17 maja 1989 r. zob. Michał Pietrzak, „Geneza ustaw wyznaniowych z 17 maja 1989 r.,” w: Prawo wyznaniowe $w$ Polsce (1989-2009). Analizy-dyskusje-postulaty, red. Dariusz Walencik (Katowice Bielsko-Biała: Wyższa Szkoła Bankowości i Finansów w Bielsku-Białej, 2009), 11-26.

${ }^{43}$ Zob. szerzej: Tadeusz J. Zieliński, ,Ustawa o gwarancjach wolności sumienia i wyznania jako „magna charta" swobód światopoglądowych w Polsce,” w: Prawo wyznaniowe w Polsce (1989-2009)..., 53-65. 
Już art. 1 ust. 3 ustawy stwierdza, że obywatele wierzący wszystkich wyznań oraz niewierzący mają równe prawa w życiu państwowym, politycznym, gospodarczym, społecznym i kulturalnym. Sformułowany w tym przepisie zakaz dyskryminacji ze względu na przekonania w sprawach religijnych został ujęty od strony pozytywnej, jako nakaz zapewnienia równych praw praktycznie we wszystkich nieosobistych sferach życia. Gwarancja ustawowa odnosi się do wszystkich, nie tylko do obywateli, ponieważ art. 7 ust. 1 stanowi, że cudzoziemcy przebywający na terytorium Rzeczypospolitej Polskiej korzystają z wolności sumienia i wyznania na równi z obywatelami polskimi, zaś zgodnie z ust. 2. art. 7, przepis ust. 1 stosuje się odpowiednio do bezpaństwowców. Należy odnotować, że ustawowy zakaz dyskryminacji ze względu na kryterium przekonań w sprawach religijnych nie dotyczy sfery życia prywatnego, w tym osobistego, zwłaszcza sfery wewnętrznej działalności związków wyznaniowych ${ }^{44}$.

Jednakże ustawodawca polski dyskryminuje osoby niebędące obywatelami polskimi $\mathrm{w}$ jednej istotnej sferze wolności sumienia i wyznania w wymiarze kolektywnym, bowiem tylko osoby będące obywatelami polskimi mogą wystąpić do ministra właściwego do spraw wyznań religijnych o wpis wspólnoty religijnej do rejestru kościolów i innych związków wyznaniowych. Nie ma natomiast żadnych przeszkód formalnoprawnych dla wstąpienia cudzoziemców do już zarejestrowanych związków wyznaniowych. Restrykcyjny i dyskryminacyjny charakter wspomnianego ograniczenia uwypukla ustawa z 7 kwietnia 1989 r. - Prawo o stowarzyszeniach, która w art. 4 ust. 1 dopuszcza tworzenie stowarzyszeń przez cudzoziemców zamieszkałych w Polsce. Co więcej, dopuszczalne jest założenie i funkcjonowa-

${ }^{44} \mathrm{~W}$ związku z zakazem dyskryminacji ze względu na wyznanie w dziedzinie m.in. życia gospodarczego konieczne jest formalne uchylenie ustawy z dnia 25 marca 1938 r. w sprawie wytwarzaniu i handlu dewocjonaliami i przedmiotami kultu religijnego (Dz. U. Nr 19, poz. 148). Ustawa ta wprowadza w zakresie produkcji i handlu dewocjonaliami oraz przedmiotami kultu religijnego segregację wyznaniową przewidując, że wytwarzaniem i sprzedażą dewocjonaliów religii chrześcijańskiej, mojżeszowej oraz muzułmańskiej mogą zajmować się odpowiednio jedynie ich wyznawcy. W chwili ustanowienia ustawa rzeczona miała faktycznie skutki antysemickie, ponieważ Żydzi masowo w II RP trudnili się produkcją i sprzedażą dewocjonaliów chrześcijańskich. 
nie stowarzyszenia skupiającego jedynie cudzoziemców, a także takiego, w którym - z uwagi na wymogi statutowe - cudzoziemcy stanowić będą większość. Zaznaczyć należy, że status członkowski cudzoziemców, w stowarzyszeniach funkcjonujących w myśl prawa o stowarzyszeniach, jest identyczny ze statusem obywateli polskich ${ }^{45}$. Ograniczenia dotyczące rejestracji związków wyznaniowych należy uznać za sprzeczne z art. 18 Traktatu o funkcjonowaniu Unii Europejskiej, zakazującego dyskryminacji obywateli UE ze względu na przynależność państwową ${ }^{46}$. Zatem te ograniczenia należałoby uznać za uchylone w odniesieniu do obywateli UE z chwilą przystąpienia Polski do tej organizacji. Jednak w praktyce krytykowane postanowienia ustawy o gwarancjach wolności sumienia i wyznania wciąż są stosowane przez centralną administrację wyznaniową.

Szczególne gwarancje niedyskryminacji ze względu na zaangażowanie religijne zostały $\mathrm{w}$ ustawie o gwarancjach wolności sumienia i wyznania zapewnione osobom duchownym. Zgodnie $\mathrm{z}$ art. 12 ust. 1 duchowni oraz osoby zakonne kościołów i innych związków wyznaniowych, ustanowione według przepisów prawa wewnętrznego kościoła lub innego związku wyznaniowego, korzystają z praw i podlegają obowiązkom na równi z innymi obywatelami we wszystkich dziedzinach życia państwowego, politycznego, gospodarczego, społecznego i kulturalnego. Ustawodawca zastrzegł, że są oni w ramach obowiązujących przepisów ustaw zwolnieni z obowiązków niemożliwych do pogodzenia $\mathrm{z}$ pełnieniem funkcji duchownego lub osoby zakonnej. Osoby, o których mowa w ust. 1, mają prawo do noszenia stroju duchownego, a więc jednak istnieją gwarancje, które wykraczają poza zakaz dyskryminacji, i w istocie dopuszczają swoiste prawne uprzywilejowanie osób duchownych ${ }^{47}$. Zaznaczyć należy, że art. 12 ustawy

${ }^{45}$ Paweł Sarnecki, Prawo o stowarzyszeniach. Komentarz (Kraków: Zakamycze, 2002), 31.

${ }^{46}$ Zob. Traktat o funkcjonowaniu Unii Europejskiej, red. nauk. Andrzej Wróbel, tom I, red. Dawid Miąsik, Nina Półtorak, i Marek Górski (Warszawa: Wolters Kluwer Polska, 2012), 375-376.

${ }^{47}$ Należy także zwrócić uwagę, że polskie prawo nie definiuje pojęcia osoby duchownej, duchownego, czy członka zakonu. Kwestie owe określają prawa wewnętrzne samych związków wyznaniowych, w szczególności prawo kanoniczne Kościoła Katolickiego. 
z 17 maja 1989 r., podobnie jak szereg innych jej postanowień, ma charakter deklaratywny. Ust. 3 tegoż artykułu stanowi bowiem, że uprawnienia i obowiązki osób duchownych, w myśl prawa państwowego, określają odrębne ustawy, jednak wprost zagwarantowano osobom duchownym prawo do noszenia stroju duchownego. Należy analizowane przepisy traktować jako reakcję ustawodawcy na trudne, wręcz dramatyczne, doświadczenia duchowieństwa różnych wyznań w okresie Polski Ludowej, traktowanego niejednokrotnie jak obywatele drugiej kategorii.

Pomimo, że ustawa o gwarancjach wolności sumienia i wyznania opiera się na paradygmacie równości i niedyskryminacji ze względu na przekonania $\mathrm{w}$ sprawach religijnych, to jednak osoby niewyznające światopoglądu religijnego są w jakiejś mierze dyskryminowane w wymiarze kolektywnym. Ustawa w art. 2 przyznaje, w ramach wolności sumienia i wyznania, obywatelom (a także cudzoziemcom i odpowiednio - bezpaństwowcom), uprawnienie do tworzenia związków wyznaniowych, a także do należenia bądź nienależenia do tego typu korporacji (zob. pkt 1 i 2a). Zarazem deklaruje ona uprawnienie do zrzeszania się w organizacjach świeckich, w celu realizacji zadań wynikających z wyznawanej religii bądź przekonań w sprawach religii (zob. pkt 11). Wszakże już z samego sformułowania art. 2 wynika, że związki wyznaniowe i organizacje laickie nie są postrzegane przez ustawodawcę na zasadzie równości. W dalszej części analizowanego aktu, ustawodawca wyróżnił zdecydowanie korporacje (wspólnoty) religijne. Tylko wspólnoty religijne, pod warunkiem spełnienia wymogów formalnych, określonych w ustawie o gwarancjach wolności sumienia i wyznania (zob. art. 30-32), mogą być zarejestrowane przez ministra właściwego do spraw wyznań religijnych. Uzyskują one wówczas oficjalnie status związków wyznaniowych i mogą korzystać z szeregu szczególnych uprawnień, które prawo polskie przewiduje dla tego rodzaju organizacji. Uprawnienia te dotyczą zwłaszcza przywilejów o charakterze finansowym.

Zatem w omawianym zakresie osobowym to prawa wewnętrzne wyznań określają zakres wyłączeń spod norm prawa powszechnie obowiązującego. 
Zgodnie z art. 13 ust. 2 ustawy o gwarancjach wolności sumienia i wyznania osoby prawne kościołów i innych związków wyznaniowych są zwolnione od opodatkowania z tytułu przychodów ze swojej działalności niegospodarczej. W tym zakresie osoby te nie mają nawet obowiązku prowadzenia dokumentacji, wymaganej przez przepisy podatkowe. Stwarza to realne niebezpieczeństwo zachowań przestępczych, np. tzw. prania brudnych pieniędzy, czy finansowania grup ekstremistycznych. Dochody z działalności gospodarczej osób prawnych kościołów i innych związków wyznaniowych oraz spółek, których udziałowcami są wyłącznie te osoby, są zwolnione od opodatkowania w części, w jakiej zostały przeznaczone w roku podatkowym lub w roku po nim następującym na cele kultowe, oświatowo-wychowawcze, naukowe, kulturalne, działalność charytatywno-opiekuńczą, punkty katechetyczne, konserwację zabytków oraz na inwestycje sakralne i inwestycje kościelne, których przedmiotem są punkty katechetyczne i zakłady charytatywno-opiekuńcze, jak również remonty tych obiektów (art. 13 ust. 5). Ponadto, zgodnie z art. 13 ust. 6 ustawy, osoby prawne kościołów i innych związków wyznaniowych są zwolnione z podatku od nieruchomości lub ich części, stanowiących własność tych osób lub używanych przez nie na podstawie innego tytułu prawnego na cele niemieszkalne, $\mathrm{z}$ wyjątkiem części zajmowanej na wykonywanie działalności gospodarczej. Związki wyznaniowe korzystają także z pewnych, wyraźnie ograniczonych w związku z członkostwem Polski w Unii Europejskiej, szczególnych preferencji celnych. Zwalnia się bowiem z należności celnych przywozowych towary przeznaczone na cele charytatywno-opiekuńcze i oświatowo-wychowawcze oraz towary o charakterze kulturalnym, przeznaczone na cele kultu, przywożone dla osób prawnych kościołów i innych związków wyznaniowych, w granicach i na warunkach określonych w rozporządzeniu Rady (WE) nr 1186/2009 z dnia 16 listopada 2009 r. ustanawiającym wspólnotowy system zwolnień celnych ${ }^{48}$. Państwo wspiera ponadto pośrednio związki wyznaniowe poprzez zwolnienia od podatku dochodowego darowizn na cele kultu religijnego. Podatnicy, będący osobami fizycznymi, mogą odliczyć od podstawy opodatkowania właściwym podatkiem dochodo-

${ }^{48}$ Dz. Urz. UE L 342 z 10.12.2009, s. 23. 
wym (PIT) darowizny na wspomniane cele, do $6 \%$ podstawy wymiaru. Natomiast podatnicy będący osobami prawnymi, z reguły dysponujący większymi środkami finansowymi, mogą odliczyć od podstawy wymiaru właściwego podatku dochodowego (CIT) darowizny na rzeczone cele, w wysokości do $10 \%$ podstawy wymiaru tego podatku.

Osoby duchowne, w przeciwieństwie do animatorów organizacji laickich, korzystają z wymiernego wsparcia finansowego z budżetu państwa, bowiem Fundusz Kościelny ${ }^{49}$ dofinansowuje w przeważającej mierze (od 80\% do 100\%) składki na ubezpieczenie społeczne osób duchownych; w całości finansuje składki na ubezpieczenie zdrowotne osób przygotowujących się do stanu duchownego (zakonnego) oraz częściowo osób, które zostały już przyjęte do tych stanów. Należy odnotować, że tylko związki wyznaniowe, zarejestrowane, mogą nauczać religii (katecheza) w ramach systemu oświaty publicznej. $\mathrm{Z}$ tego tytułu nauczyciele religii otrzymują wynagrodzenie ze środków publicznych.

Należy zauważyć, że kontrola aparatu państwowego nad zarejestrowanymi już związkami wyznaniowymi jest łagodniejsza, niż organów sądowych nad stowarzyszeniami wpisanymi do Krajowego Rejestru Sądowego. Przykładowo, Departament Wyznań Religijnych oraz mniejszości Narodowościowych i Etnicznych MAiC od 2008 r. nie kontroluje, czy zmiana prawa wewnętrznego związków wyznaniowych - mają one obowiązek zgłosić zmiany centralnej administracji wyznaniowej - została dokonana zgodnie z dotychczas obowiązującym prawem wewnętrznym.

Zaznaczyć należy, że w polskim systemie prawnym traktowanie przez ustawodawcę tzw. organizacji laickich na równi ze związkami wyznaniowymi jest wyjątkowo rzadkie. Przykładem takiej regulacji jest ustawa z 24 kwietnia 2003 r. o organizacjach pożytku publicznego i o wolontariacie ${ }^{50}$, która w art. 3 ust. 3 pkt 3 przewiduje, że działalność

${ }^{49}$ Podstawą normatywną działania Funduszu Kościelnego są zwłaszcza art. 8-10 ustawy z dnia 20 marca 1950 r. o przejęciu przez Państwo dóbr martwej ręki, poręczeniu proboszczom posiadania gospodarstw rolnych i utworzeniu Funduszu Kościelnego (Dz. U. Nr 9, poz. 87 z późn. zm.).

${ }^{50}$ Tekst jedn. Dz. U. z 2014 r. poz. 1118 z późn. zm. 
pożytku publicznego mogą prowadzić także osoby prawne $i$ jednostki organizacyjne dziatajace na podstawie przepisów o stosunku Państwa do Kościoła Katolickiego w Rzeczypospolitej Polskiej, o stosunku Państwa do innych kościołów i zwiazków wyznaniowych oraz o gwarancjach wolności sumienia $i$ wyznania, jeżeli ich cele statutowe obejmuja prowadzenie działalności pożytku publicznego. Działalność pożytku publicznego mogą zatem prowadzić, na takich samych zasadach jak jednostki organizacyjne związków wyznaniowych, także organizacje świeckie, tworzone w celu realizacji zadań wynikających z przekonań w sprawach religii (por. art. 2 pkt 11 ustawy o gwarancjach wolności sumienia i wyznania). Trzeba podkreślić, że we współczesnej Europie, mimo wyraźnych w ostatnich dziesięcioleciach procesów laicyzacyjnych, rzadkie jest traktowanie w ustawodawstwie krajowym organizacji laickich na równi ze związkami wyznaniowymi ${ }^{51}$, bowiem wciąż jest żywa na Starym Kontynencie tradycja kościoła państwowego.

Ustawa o gwarancjach wolności sumienia i wyznania formułuje ponadto gwarancje niedyskryminacji ze względu na przekonania w sprawach religijnych. Przede wszystkim w art. 10 ust. 1 została wyrażona zasada, iż Rzeczypospolita Polska jest państwem świeckim, neutralnym w sprawach religii i przekonań. Taką gwarancją jest także wyraźnie wyróżnione w art. 2 pkt 5 prawo jednostki do zachowania milczenia $\mathrm{w}$ sprawach swojej religii lub przekonań. Ponadto funkcję gwarancyjną pełnią zasady: oddzielenia kościołów i innych związków wyznaniowych od państwa (art. 9 ust. 2 pkt 1) oraz równouprawnienia wszystkich kościołów i innych związków wyznaniowych, bez względu na formę uregulowania ich sytuacji prawnej (art. 9 ust. 2 pkt 3).

Wyraźną słabością ustawy o gwarancjach wolności sumienia i wyznania jest brak bezpośrednich sankcji karnych za naruszenie jej postanowień, w szczególności przepisów mających służyć niedyskryminacji ze względu na religię lub światopogląd. Nadaje to wielu istotnym, fundamentalnym przepisom tej regulacji, charakter deklaratywny. Szereg fundamentalnych norm wynikających $\mathrm{z}$ omawianej ustawy to dobry przykład lex imperfecta.

${ }^{51}$ Przykładem nielicznych państw, w których można mówić o pewnym egalitaryzmie związków wyznaniowych i organizacji laickich są: Belgia, Norwegia, czy Niemcy. 
2. GWARANCJE USTAWOWE ZAKAZU DYSKRYMINACJI ZE WZGLĘDU NA RELIGIĘ (WYZNANIE) LUB ŚWIATOPOGLĄD (BEZWYZNANIOWOŚĆ) W SFERZE ZATRUDNIENIA.

Ustawa z 1974 r. Kodeks pracy ${ }^{52}$ (KP) za niedopuszczalną uznaje $\mathrm{w}$ art. $11^{3}$ jakąkolwiek dyskryminację $\mathrm{w}$ zatrudnieniu, bezpośrednią lub pośrednią, w szczególności ze względu na religię, narodowość, wyznanie. Pojęcie wyznania należy interpretować szeroko; obejmuje ono zatem również wyznawanie światopoglądu niereligijnego, czy bezwyznaniowość. Zagadnieniu równego traktowania w zatrudnieniu, zatem niedyskryminacji, poświęcono specjalną jednostkę w Dziale I KP, Rozdział IIa zatytułowany „Równe traktowanie w zatrudnieniu”. Jego treść stanowi wyraz dążenia do urzeczywistnienia w polskim prawie standardów w zakresie zwalczania niedopuszczalnej dyskryminacji w dziedzinie zatrudnienia, m.in. ze względu na religię (wyznanie) lub światopogląd, sformułowanych w Dyrektywie Rady 2000/78/ WE z dnia 27 listopada 2000 r., ustanawiającej ogólne warunki ramowe równego traktowania w zakresie zatrudnienia i pracy.

W art. $18^{3 a} \S 1$ Kodeksu pracy sformułowano jednoznaczny, zarazem szczegółowy nakaz, aby pracownicy byli równo traktowani w zakresie nawiązania i rozwiązania stosunku pracy, warunków zatrudnienia, awansowania oraz dostępu do szkolenia w celu podnoszenia kwalifikacji zawodowych, bez względu na religię, narodowość i wyznanie. Dążąc do urzeczywistnienia Dyrektywy Rady z 27 listopada 2000 r. ustawodawca polski sformułował definicję równego traktowania w zatrudnieniu, utożsamiając ją z niedyskryminacją zarówno bezpośrednią jak i pośrednią w jakikolwiek sposób, z przyczyn wymienionych $\mathrm{w}$ rzeczonym przepisie (zob. art. $18^{3 \mathrm{a}} \S 2 \mathrm{KP}$ ). Zdefiniowano następnie po raz pierwszy w polskim prawie pojęcie dyskryminacji bezpośredniej i dyskryminacji pośredniej. Dyskryminowanie bezpośrednie istnieje zatem wtedy, gdy pracownik z jednej lub z kilku przyczyn określonych w $\S 1$ był, jest lub mógłby być traktowany w porównywalnej sytuacji mniej korzystnie niż inni pracownicy (art. $\left.18^{3 a} \S 3 \mathrm{KP}\right)$. Natomiast dyskryminowanie pośrednie istnieje

${ }^{52}$ Tekst jedn. Dz. U. z 2014 r., poz. 1502 z późn. zm. 
wtedy, gdy na skutek pozornie neutralnego postanowienia, zastosowanego kryterium lub podjętego działania, występują lub mogłyby wystąpić niekorzystne dysproporcje albo szczególnie niekorzystna sytuacja w zakresie nawiązania i rozwiązania stosunku pracy, warunków zatrudnienia, awansowania oraz dostępu do szkolenia w celu podnoszenia kwalifikacji zawodowych wobec wszystkich lub znacznej liczby pracowników należących do grupy wyróżnionej ze względu na jedną lub kilka przyczyn określonych w $\S 1$, chyba że postanowienie, kryterium lub działanie jest obiektywnie uzasadnione ze względu na zgodny z prawem cel, który ma być osiągnięty, a środki służące osiągnięciu tego celu są właściwe i konieczne (art. $18^{3 \mathrm{a}} \S 4 \mathrm{KP}$ ).

Kodeks pracy zmierza do wyeliminowania nawet „subtelnych”, niejako pośrednich, form dyskryminacji. Za przejaw zakazanego dyskryminowania uznaje ponadto:

1) działanie polegające na zachęcaniu innej osoby do naruszenia zasady równego traktowania w zatrudnieniu lub nakazaniu jej naruszenia tej zasady;

2) niepożądane zachowanie, którego celem lub skutkiem jest naruszenie godności pracownika i stworzenie wobec niego zastraszającej, wrogiej, poniżającej, upokarzającej lub uwłaczającej atmosfery (molestowanie) (zob. art. $18^{3 \mathrm{a}} \S 5 \mathrm{KP}$ ).

$\mathrm{W}$ myśl art. $18^{3 \mathrm{~b}} \S 1 \mathrm{KP}$ za naruszenie zasady równego traktowania $\mathrm{w}$ zatrudnieniu, z zastrzeżeniem $\S 2-4$, uważa się także różnicowanie przez pracodawcę sytuacji pracownika z jednej lub kilku przyczyn określonych $\mathrm{w}$ art. $18^{3 \mathrm{a}} \S 1 \mathrm{KP}$ (czyli również ze względu na religię lub światopogląd), którego skutkiem jest:

1) odmowa nawiązania lub rozwiązanie stosunku pracy,

2) niekorzystne ukształtowanie wynagrodzenia za pracę lub innych warunków zatrudnienia albo pominięcie przy awansowaniu lub przyznawaniu innych świadczeń związanych z pracą,

3) pominięcie przy typowaniu do udziału w szkoleniach podnoszących kwalifikacje zawodowe, chyba że pracodawca udowodni, że kierował się obiektywnymi powodami.

Według art. $18^{3 \mathrm{~b}} \S 2 \mathrm{KP}$ zasady równego traktowania w zatrudnieniu nie naruszają działania, proporcjonalne do osiągnięcia zgodnego z prawem celu, różnicowania sytuacji pracownika, polegającego na: 
1) niezatrudnianiu pracownika $\mathrm{z}$ jednej lub kilku przyczyn określonych $w$ art. $18^{\text {za }} \S 1$, jeżeli rodzaj pracy lub warunki jej wykonywania powodują, że przyczyna lub przyczyny wymienione w tym przepisie są rzeczywistym i decydującym wymogiem zawodowym, stawianym pracownikowi;

2) wypowiedzeniu pracownikowi warunków zatrudnienia w zakresie wymiaru czasu pracy, jeżeli jest to uzasadnione przyczynami niedotyczącymi pracowników bez powoływania się na inną przyczynę lub inne przyczyny wymienione w art. $18^{3 \mathrm{a}} \S 1$ i $\S 3$, które różnicują sytuację prawną pracownika, ze względu na ochronę rodzicielstwa lub niepełnosprawność;

4) stosowaniu kryterium stażu pracy przy ustalaniu warunków zatrudniania i zwalniania pracowników, zasad wynagradzania i awansowania oraz dostępu do szkolenia w celu podnoszenia kwalifikacji zawodowych, co uzasadnia odmienne traktowanie pracowników ze względu na wiek.

Zgodnie $\mathrm{z}$ art. $18^{3 \mathrm{~b}} \S 3$ Kodeksu pracy nie stanowią naruszenia zasady równego traktowania $\mathrm{w}$ zatrudnieniu także działania podejmowane przez określony czas, zmierzające do wyrównywania szans wszystkich lub znacznej liczby pracowników, wyróżnionych z jednej lub kilku przyczyn określonych $\mathrm{w}$ art. $18^{3 \mathrm{a}} \S 1 \mathrm{KP}$, przez zmniejszenie na ich korzyść faktycznych nierówności, w zakresie określonym w tym przepisie.

Ustawodawca przewidział istotny wyjątek od zasady egalitaryzmu w zatrudnieniu, zgodnie ze standardami wynikającymi z Dyrektywy Rady z 27 listopada 2000 r. w odniesieniu do wspólnot religijnych oraz organizacji laickich. Zgodnie z art. 18 § 4 Kodeksu nie stanowi naruszenia zasady równego traktowania ograniczanie przez kościoły i inne związki wyznaniowe a także organizacje, których etyka opiera się na religii, wyznaniu lub światopoglądzie, dostępu do zatrudnienia, ze względu na religię, wyznanie lub światopogląd, jeżeli rodzaj lub charakter wykonywania działalności przez kościoły i inne związki wyznaniowe a także organizacje powoduje, że religia, wyznanie lub światopogląd są rzeczywistym i decydującym wymaganiem zawodowym stawianym pracownikowi, proporcjonalnym do osiągnięcia zgodnego z prawem celu. Dotyczy to również wymagania od zatrud- 
nionych działania w dobrej wierze i lojalności wobec etyki kościoła, innego związku wyznaniowego oraz organizacji, których etyka opiera się na religii, wyznaniu lub światopoglądzie. Dlatego też pracodawca religijny, czy światopoglądowy ma prawo dobierać sobie pracowników w oparciu o kryterium akceptowania określonych przekonań w sprawach konfesyjnych, jak również oczekiwać respektowania przez nich norm etycznych lansowanych przed daną organizację.

3. OCHRONA PRZED DYSKRYMINACJĄ ZE WZGLĘDU NA RELIGIĘ, WYZNANIE LUB ŚWIATOPOGLĄD W USTAWIE „ANTYDYSKRYMINACYJNEJ”.

Ustawa ,antydyskryminacyjna”, czyli ustawa z dnia 3 grudnia 2010 r. o wdrożeniu niektórych przepisów Unii Europejskiej w zakresie równego traktowania, wbrew swojej potocznej nazwie, nie zapewnia wszechstronnej ochrony przed dyskryminacją, szczególnie opartą na kryterium religii, wyznania lub światopoglądu. Ustawy tej nie stosuje się m.in. do sfery życia prywatnego i rodzinnego oraz czynności prawnych, pozostających w związku z tymi sferami, oraz do ograniczania przez kościoły i inne związki wyznaniowe a także organizacje, których etyka opiera się na religii, wyznaniu lub światopoglądzie, dostępu do działalności zawodowej oraz jej wykonywania, ze względu na religię, wyznanie lub światopogląd, jeżeli rodzaj lub warunki wykonywania takiej działalności powodują, że religia, wyznanie lub światopogląd są rzeczywistym i decydującym wymogiem zawodowym stawianym danej osobie fizycznej, proporcjonalnym do osiągnięcia zgodnego z prawem celu. Dotyczy to również wymagania od zatrudnionych osób fizycznych działania w dobrej wierze i lojalności wobec etyki kościoła, innego związku wyznaniowego oraz organizacji, których etyka opiera się na religii, wyznaniu lub światopoglądzie.

Ochrona przed dyskryminacją ze względu na religię, wyznanie lub światopogląd w świetle ustawy z 3 grudnia 2010 r. jest wyraźnie ograniczona. Zgodnie $\mathrm{z}$ art. 8 ust. 1 zakazane jest nierówne traktowanie osób fizycznych, lecz już nie osób prawnych czy innych jednostek organizacyjnych, m.in. ze względu na wymienione kryteria w ściśle określonym zakresie: 
1) podejmowania kształcenia zawodowego, w tym dokształcania, doskonalenia, przekwalifikowania zawodowego oraz praktyk zawodowych;

2) warunków podejmowania i wykonywania działalności gospodarczej lub zawodowej, w szczególności w ramach stosunku pracy albo pracy na podstawie umowy cywilnoprawnej;

3) przystępowania i działania w związkach zawodowych, organizacjach pracodawców oraz samorządach zawodowych, a także korzystania z uprawnień przysługujących członkom tych organizacji;

4) dostępu i warunków korzystania $z$ instrumentów rynku pracy i usług rynku pracy określonych w ustawie z dnia 20 kwietnia 2004 r. o promocji zatrudnienia i instytucjach rynku pracy oferowanych przez instytucje rynku pracy oraz instrumentów rynku pracy i usług rynku pracy oferowanych przez inne podmioty działające na rzecz zatrudnienia, rozwoju zasobów ludzkich i przeciwdziałania bezrobociu.

Ponadto ustawodawca wyraźnie zastrzegł, iż [n]ie stanowi naruszenia zakazu, o którym mowa w art. 8 ust. 1 ustawy, nierówne traktowanie ze względu $w$ szczególności na religię, wyznanie czy światopogląd $w$ zakresie podejmowania środków koniecznych $w$ demokratycznym państwie dla jego bezpieczeństwa publicznego i porzadku, ochrony zdrowia lub ochrony wolności i praw innych osób oraz zapobiegania działaniom podlegajacym sankcjom karnym, w zakresie określonym $w$ innych przepisach.

\section{GWARANCJE NIEDYSKRYMINACJI ZE WZGLĘDU NA PRZEKONANIA} W SPRAWACH RELIGIJNYCH W USTAWODAWSTWIE KARNYM.

Dyskryminacja ze względu na wyznanie lub bezwyznaniowość podlega w polskim prawie kryminalizacji. Zgodnie z art. 194 Kodeksu karnego z 1997 r. (k.k.), kto ogranicza człowieka w przysługujących mu prawach ze względu na jego przynależność wyznaniową albo bezwyznaniowość, podlega grzywnie, karze ograniczenia wolności albo pozbawienia wolności do lat 2. Rzeczone przestępstwo może być popełnione jedynie w zamiarze bezpośrednim. Zatem w szczególności należy 
podzielić stanowisko, że jeżeli [...] ktoś uprzywilejowuje dana osobę w przystugujacych jej prawach ze względu na jej przynależność wyznaniowa lub bezwyznaniowość, to można mu postawić zarzut popetnienia przestępstwa z art. 194 k.k. tylko wówczas, gdy jednocześnie wiedziat o przynależności wyznaniowej innej osoby, która na skutek tego uprzywilejowania została ograniczona $w$ jej prawach ${ }^{53}$. Zwraca się uwagę, że przynależność wyznaniowa, o której mowa w analizowanym przepisie, oznacza uczestnictwo w określonej wspólnocie religijnej. Zarazem jednak zgodność wyobrażenia sprawcy co do tego, członkiem jakiej konkretnie wspólnoty religijnej jest pokrzywdzony, w rzeczywistości nie ma znaczenia dla bytu przestępstwa z art. 194 k.k. ${ }^{54}$ Zakres osobowy ochrony wynikającej $\mathrm{z}$ analizowanego przepisu obejmuje także grupy osób, zwłaszcza zorganizowanych w związki wyznaniowe ${ }^{55}$. Językowa forma art. 194 k.k. wskazuje także, że kryminalizacją objęta jest dyskryminacja dzieci ze względu na ich przynależność wyznaniową albo bezwyznaniowość, także wówczas, gdy dopuszczają się jej rodzice np. w rodzinach zróżnicowanych religijnie lub światopoglądowo ${ }^{56}$.

Należy jednak zauważyć, że ustawa karna jednak subtelnie różnicuje poziom ochrony osób wyznających światopogląd religijny i wyznawców światopoglądu niereligijnego ${ }^{57}$. Wskazuje na to chociażby art. 196 k.k., który kryminalizuje przestępstwo obrazy uczuć religijnych innych osób, poprzez publiczne znieważenie przedmiotu czci religijnej lub miejsca przeznaczonego do publicznego wykonywania obrzędów

${ }^{53}$ Natalia Kłączyńska, „Prawnokarne znaczenie norm zawierających zakaz dyskryminacji," Nowa Kodyfikacja Prawa Karnego 12 (2003): 53-66.

54 Tamże.

${ }^{55}$ Zasadnie konstatuje N. Kłączyńska, iż [o]chrona z art. 194 k.k. obejmuje [...] prawa [człowieka przysługujące zbiorowościom]. Wprawdzie w przeciwieństwie do art. 118 i 119 k.k., dotyczacych dyskryminacji osoby lub grupy osób, art. 194 k.k. mówi o ograniczaniu człowieka w przystugujących mu prawach, ale stosowanie wykładni zawężajacej, ograniczajacej zakres zastosowania art. 194 k.k. tylko do naruszania praw jednostki, jest niedopuszczalne, prowadzi bowiem do powstania luki, w której dyskryminacja zbiorowości o określonej tożsamości światopogladowej, w szczególności związków wyznaniowych, w korzystaniu z przystugujacych im praw pozostałaby - poza szczególnymi przypadkami, o których mowa w art. 118 i 119 k.k. - bezkarna. Zob. tamże.

${ }^{56}$ Zob. szerzej tamże.

${ }^{57}$ Dążenie do zapewnienia równego poziomu ochrony wyznawców religii oraz innych form światopoglądu czytelne są, poza art. 194 k.k., także w art. 118 i art. 119 ustawy karnej. 
religijnych. Obraza uczuć związanych z innego rodzaju światopoglądem nie jest kryminalizowana. Omawiany przepis Kodeksu w sumie chroni też miejsca przeznaczone do publicznego kultu religijnego oraz przedmioty tego kultu. Jest ono ścigane z oskarżenia publicznego, co koliduje z konstytucyjną zasadą bezstronności (neutralności) światopoglądowej władz publicznych. Angażuje bowiem aparat państwa (prokuraturę) na rzecz ochrony pierwiastka religijnego. Wypada zgodzić się ze stanowiskiem, że w przypadku obrażenia uczuć osób niewierzących kwalifikacja czynu może zostać oparta nie na art. 196 k.k., ale na przepisach art. 212 k.k. (zniesławienie) lub 216 k.k. (znieważenie), a więc dotyczących przestępstw przeciwko czci, ewentualnie na art. 257 k.k., penalizującym publiczne znieważanie grupy ludności albo poszczególnej osoby z powodu jej przynależności narodowej, etnicznej, rasowej, wyznaniowej albo z powodu jej bezwyznaniowości ${ }^{58}$.

Należy zwrócić uwagę na brak w Kodeksie karnym wykonawczym (k.k.w.) szczególnych gwarancji niedyskryminacji osadzonych, zwłaszcza ze względu na religię (wyznanie) lub światopogląd (bezwyznaniowość) przez administrację zakładów penitencjarnych. Owe gwarancje pośrednio zdają się wynikać z art. $4 \S 2$ k.k.w., który stanowi, że skazany zachowuje prawa i wolności obywatelskie, a ich ograniczenie może wynikać jedynie $\mathrm{z}$ ustawy oraz $\mathrm{z}$ wydanego na jej podstawie prawomocnego orzeczenia. Opisana regulacja jest niedostateczna, bowiem osadzony znajduje się pod szczególną władzą organów zakładów penitencjarnych i jest narażony na różne formy presji ze strony personelu tych jednostek. Pomimo tego, że znajduje się on pod ich władzą - przy wyraźnie ograniczonej możliwości swobodnego kontaktowania się ze światem zewnętrznym - powinien mieć zdecydowanie lepsze gwarancje niedyskryminacji, np. poprzez przyjęcie przez ustawodawcę jedynie wymogu uprawdopodobnienia przez skarżącego osadzonego niedopuszczalnej dyskryminacji ze względu na przekonania w sprawach religijnych ze strony administracji zakładów penitencjarnych. Należy rozważyć, czy administrację zakładów penitencjarnych nie należy obciążyć, przynajmniej w ograniczonym zakresie, odpowiedzialnością

${ }^{58}$ Zob. szerzej Erwin Kruczoń, „Przestępstwo obrazy uczuć religijnych,” Prokuratura i Prawo 2 (2011): 38-59. 
za dyskryminacyjne praktyki, oparte na przekonaniach w sprawach religijnych, ze strony innych osadzonych wobec danej jednostki. Wszakże wszyscy osadzeni znajdują się pod szczególną pieczą owej administracji, która w związku z tym bierze za nich odpowiedzialność. Jest okolicznością potwierdzoną przez wielowiekowe doświadczenia z zakładów penitencjarnych, że bezczynność ich administracji, wobec współosadzonych danej osoby, może stanowić skuteczną formę presji nań, prowadzącą do różnych form autodestrukcji.

\section{PROBLEM RÓWNOUPRAWNIENIA \\ ZWIĄZKÓW WYZNANIOWYCH W PRAWIE POLSKIM \\ A ZAKAZ DYSKRYMINACJI ZE WZGLĘDU NA WYZNANIE}

Istotnym aspektem niedyskryminacji jednostki ze względu na religię (wyznanie) jest równouprawnienie związków wyznaniowych. Jednostka, będąca osobą wyznającą religię, realizuje swoją wolność myśli, sumienia i wyznania przede wszystkim w ramach związków wyznaniowych i w oparciu o tego typu korporacje. Odrzucenie zasady równouprawnienia związków wyznaniowych musi zatem logicznie i praktycznie w ostateczności skutkować negacją zasady równego traktowania ich właściwych wyznawców, czyli rodzić dyskryminację ze względu na wyznawaną religię. Współczesna Konstytucja RP z 1997 r. jako jedna z nielicznych ustaw zasadniczych w Europie gwarantuje kościołom i innym związkom wyznaniowym równouprawnienie (art. 25 ust. 1) ${ }^{59}$. Wykładnia prowadzi do wniosku, że władze publiczne mają obowiązek zapewnić wszystkim związkom wyznaniowym uprawnienia tego samego rodzaju i tej samej miary. Wspomniany obowiązek dotyczy przede wszystkim uprawnień w sensie norma-

${ }^{59}$ Drugą ustawą zasadniczą w Europie, która wprost formułuje zasadę równouprawnienia związków wyznaniowych jest Konstytucja Słowenii z 1991 r. w art. 7. Stanowi on: Państwo $i$ wspólnoty religijne sa rozdzielone. Wspólnoty religijne sa równouprawnione; przystuguje im swoboda działalności. W wersji oryginalnej przepis ten brzmi: Država in verske skupnosti so ločene. Verske skupnosti so enakopravne; njihovo delovanje je svobodno. - źródło: http://www.us-rs.si/index.php?sv_path=3583,3519 [dostęp: 8.12.2014]. 
tywnym ${ }^{60}$, czyli, ujmując sprawę lapidarnie, oznacza równość szans i równy start $\mathrm{w}$ aspekcie prawnym. Władze publiczne zobligowane są zapewnić równe uprawnienia faktycznie, lecz to od związku wyznaniowego zależy, czy z opisanych możliwości prawnych i faktycznych skorzysta. Odstąpienie od tej zasady może nastąpić tylko za zgodą samego zainteresowanego, czyli związku wyznaniowego, w szczególności wyrażoną w umowie zawartej z Radą Ministrów zgodnie z art. 25 ust. 5 Konstytucji, mającej stanowić podstawę odpowiedniej ustawy. $\mathrm{Z}$ art. 25 ust. 1 ustawy zasadniczej wynika dla władz publicznych obowiązek niepreferowania żadnej $\mathrm{z}$ istniejących w Polsce wspólnot religijnych. Zarazem jednak $z$ tego przepisu nie wynika zakaz popierania związków wyznaniowych, jako nośników określonego światopoglądu religijnego. Należy więc zgodzić się z Trybunałem Konstytucyjnym oraz komentatorami, że analizowany przepis uniemożliwia ustanowienie w Polsce wyznania, czy kościoła państwowego, a także aprecjację normatywną określonej grupy związków wyznaniowych, ze względu na rodzaj głoszonego wyznania (np. katolicyzmu), czy religii (np. monoteistycznych czy judeochrześcijańskich). Art. 25 ust. 1, rozpatrywany samodzielnie, nie wyklucza jednak ustanowienia swoistego państwa poli-wyznaniowego, zarazem jednak zasada równouprawnienia związków wyznaniowych wyklucza możliwość prowadzenia przez władze publiczne działań afirmatywnych wobec mniejszości religijnych. Art. 25 ust. 1 nie formułuje ponadto ekspektatywy równości faktycznej.

$\mathrm{Na}$ bezpośredni związek zasady równouprawnienia związków wyznaniowych $\mathrm{z}$ zasadą niedyskryminacji jednostki ze względu na wyznanie wskazuje wybiórcze przyznanie przez ustawodawcę w 1998 r., tylko dziesięciu kościołom chrześcijańskim oraz Związkowi Gmin Wyznaniowych Żydowskich w RP, prawa do udzielania tzw. ślubów wyznaniowych ze skutkami cywilnymi ${ }^{61}$. Uprawnienia tego

${ }^{60}$ Por. zbieżnie Małgorzata Winiarczyk-Kossakowska, Państwowe prawo wyznaniowe w praktyce administracyjnej (Warszawa: Scholar, 1999), 31; Piotr Winczorek, Komentarz do Konstytucji Rzeczypospolitej Polskiej z dnia 2 kwietnia 1997 r. (Warszawa: Liber, 2000), 38.

${ }^{61}$ Zob.: ustawa z dnia 24 lipca 1998 r. o zmianie ustaw - Kodeks rodzinny i opiekuńczy, Kodeks postępowania cywilnego, Prawo o aktach stanu cywilnego, ustawy o stosunku 
nie otrzymał m.in. żaden z muzułmańskich związków wyznaniowych, nawet Muzułmański Związek Religijny mający tradycje od 1925 r. i to pomimo, że islam posiada rozbudowane normy prawa małżeńskiego o wielowiekowej tradycji, zaś przypadki poligamii wśród polskich muzułmanów od schyłku XIV były incydentalne. Decyzja władz ma zatem charakter uznaniowy ${ }^{62}$. W jej wyniku nie tylko pewne związki wyznaniowe zostały dowartościowane, a ich funkcjonariusze, w pewnej mierze, pełnią funkcję urzędników stanu cywilnego, ale wierni tych związków wyznaniowych lub osoby zamierzające z owymi wiernymi zawrzeć związek małżeński są $\mathrm{w}$ istotnej mierze zwolnione $\mathrm{z}$ części kosztów ceremonii ślubnych. Przygotowują się tylko do ceremonii wyznaniowej, z wyłączeniem ceremonii cywilnej w Urzędzie Stanu Cywilnego.

Inne odstępstwo od zasady równouprawnienia związków wyznaniowych, ściśle wiążące się z zakazem dyskryminacji bez względu na wyznanie, dotyczy zróżnicowania preferencji na rzecz darczyńców wspierających działalność charytatywno-opiekuńczą, prowadzoną przez związki wyznaniowe. Skala owych preferencji jest zróżnicowana w zależności od związków wyznaniowych. W największym zakresie dotyczy Kościoła Katolickiego oraz Polskiego Autokefalicznego Kościoła Prawosławnego. Darczyńcy (zarówno osoby fizyczne jak i osoby prawne) na rzecz działalności charytatywno-opiekuńczej - prowadzonej przez właściwe wyznaniowe osoby prawne tych konfesji - mogą odliczyć darowizny od podstawy opodatkowania, bez

państwa do Kościoła Katolickiego w Rzeczypospolitej Polskiej oraz niektórych innych ustaw (Dz. U. Nr 117, poz. 757).

${ }^{62}$ Związkami wyznaniowymi posiadającymi prawo do udzielania małżeństw ze skutkami cywilnymi, czy też jak chce część doktryny prawa wyznaniowego - małżeństw cywilnych w formie wyznaniowej, są: Kościół Katolicki, Polski Autokefaliczny Kościół Prawosławny, Kościół Ewangelicko-Augsburski w Rzeczypospolitej Polskiej (RP), Kościół Ewangelicko-Reformowany w RP, Kościół Ewangelicko-Metodystyczny w RP, Kościół Chrześcijan Baptystów, Kościół Adwentystów Dnia Siódmego w RP, Kościół Polskokatolicki w RP, Kościół Starokatolicki Mariawitów w RP oraz Związek Gmin Wyznaniowych Żydowskich w RP. Spośród związków wyznaniowych, którym zaproponowano na etapie wstępnym właściwych prac ustawodawczych przyznanie tego rodzaju uprawnień nie wyraził nimi zainteresowania jedynie Kościół Katolicki Mariawitów w RP. 
względu na ich wysokość, czyli nawet do 100\% uzyskanego dochodu ${ }^{63}$. W przypadku kościołów chrześcijańskich, działających na podstawie indywidualnych ustaw wyznaniowych z lat 1994-1997, darowizny na działalność charytatywno-opiekuńczą mogą odliczyć bez ograniczeń podatnicy będący osobami fizycznymi ${ }^{64}$. Osoby prawne, z reguły posiadające większe środki finansowe niż osoby fizyczne, mogą odliczyć wspomnianego rodzaju darowizny do wysokości procentowo określonej w ogólnej ustawie podatkowej. W przypadku innych związków wyznaniowych, darowizny na działalność charytatywno-opiekuńczą, podatnicy mogą odliczyć od podstawy opodatkowania właściwym podatkiem dochodowym (PIT, CIT) do wysokości określonej procentowo podstawy opodatkowania, zgodnie z ogólnym ustawodawstwem podatkowym.

Ewidentnie dyskryminacyjna, ze względu na wyznanie, jest norma wynikająca $\mathrm{z}$ art. 2 ust. 1 ustawy z dnia 20 lutego 1997 r. o stosunku Państwa do gmin wyznaniowych żydowskich w RP ${ }^{65}$, przewidująca, że członkiem gminy wyznaniowej żydowskiej może być tylko pełnoletni obywatel polski wyznania mojżeszowego, zamieszkały w Polsce. Jest to regulacja jaskrawo naruszająca wewnętrzną autonomię gmin wyznaniowych żydowskich w RP, które powinny wyłącznie same, w swoim prawie wewnętrznym, określać kryteria członkostwa. W stosunku do żadnego innego związku wyznaniowego ustawodawca polski nie sformułował tak wyśrubowanych wymogów, które naruszają wolność sumienia i wyznania w wymiarze indywidualnym, a także kolektywnym $^{66}$. Można zasadnie przypuszczać, że u podstaw tej normy znalazły

${ }^{63}$ Ten stan prawny doczekał się jednak legitymizacji ze strony Naczelnego Sądu Administracyjnego w uchwale z 14 marca 2005 r. (FDS 5/04, ONSAiWSA 2005, Nr 3, poz. 49). Zob. krytyczną do tej uchwały glosę Pawła Boreckiego, Zeszyty Naukowe Sądownictwa Administracyjnego 2-3 (2005): 148-157.

${ }^{64}$ Są to: Kościół Ewangelicko-Augsburski w RP, Kościół Ewangelicko-Reformowany w RP, Kościół Ewangelicko-Metodystyczny w RP, Kościół Chrześcijan Baptystów, Kościół Adwentystów Dnia Siódmego w RP, Kościół Polskokatolicki w RP, Kościół Starokatolicki Mariawitów w RP i Kościół Katolicki Mariawitów w RP.

${ }^{65}$ Tekst jedn. Dz. U. z 2014 r., poz. 1798.

${ }^{66}$ Por. trafne zdanie odrębne sędziego Jerzego Hermelińskiego do postanowienia Trybunału Konstytucyjnego z 18 lutego 2015 r. (sygn. akt P 48/13). Zarazem TK w postanowieniu z 18 lutego 2015 r. (sygn. akt S 2/15) przedstawił Sejmowi RP uwagi o stwierdzonym 
się stereotypy ksenofobiczne, a zwłaszcza obawy, że wobec dopuszczenia w ustawie z 20 lutego 1997 r. ograniczonej restytucji mienia dawnych gmin wyznaniowych żydowskich, uzyskane w ten sposób środki mogą zostać przejęte przez zagraniczną diasporę żydowską.

Należy zauważyć, że zjawisko dyskryminacji ze względu na wyznanie paradoksalnie dotyczy także Kościoła Katolickiego w Polsce, w zakresie obsady godności biskupów. Zgodnie z art. 7 ust. 3 Konkordatu z 28 lipca 1993 r. między Stolicą Apostolską a Rzecząpospolitą Polską ${ }^{67}$ godności te mogą być sprawowane wyłącznie przez obywateli polskich. Biskup niebędący obywatelem polskim, w myśl art. 6 traktatu, nie może należeć do Konferencji Episkopatu Polski, ani nie może sprawować jurysdykcji w Polsce, za wyjątkiem legata lub innego wysłannika papieskiego (art. 6 ust. 4). Ponadto biskup będący członkiem Konferencji Episkopatu Polski nie może należeć do krajowej konferencji episkopatu w innym państwie (art. 6 ust. 4). Wspomniane reguły, wyraźnie ograniczające niezależność Kościoła Katolickiego w Polsce w zakresie obsady jego kluczowych godności, ograniczają także szczegółową wolność wyznawania religii przez katolików możność piastowania prominentnych urzędów w swoim Kościele. Dyskryminacyjną wymowę rzeczonej regulacji osłabia fakt, że Stolica Apostolska, kierowniczy organ Kościoła Katolickiego, dobrowolnie na nie przystała, podpisując i ratyfikując Konkordat z 1993 r.

Ograniczenia nawet bardziej „wyśrubowane” od tych, które dotyczą Kościoła Katolickiego, odnoszą się do trzech związków wyznaniowych, działających na podstawie indywidualnych aktów ustawodawczych z okresu międzywojennego. Są to: Wschodni Kościół Staroobrzędowy nieposiadający hierarchii duchownej, Karaimski Związek Religijny oraz Muzułmański Związek Religijny. Jednym z ustawowych warunków piastowania stanowisk we władzach centralnych, względnie

uchybieniu w art. 2 ust. 1 ustawy z dnia 20 lutego 1997 r. o stosunku Państwa do gmin wyznaniowych żydowskich w Rzeczypospolitej Polskiej, co do polskiego obywatelstwa jako ustawowego kryterium dopuszczalności członkostwa w gminach wyznaniowych żydowskich. Usunięcie tego kryterium TK uznał zasadnie niezbędne dla zapewnienia spójności systemu prawnego Rzeczypospolitej Polskiej. Zob. http://otk.trybunal.gov.pl/orzeczenia/ otk.htm [dostęp: 16.07.2015].

${ }^{67}$ Dz. U. z 1998 r. Nr. 51, poz. 318. 
we władzach lokalnych tychże związków wyznaniowych, jest posiadanie obywatelstwa polskiego. Co więcej, wymóg posiadania obywatelstwa polskiego jest warunkiem koniecznym korzystania z biernego i czynnego prawa wyborczego w karaimskich gminach wyznaniowych oraz Muzułmańskim Związku Religijnym ${ }^{68}$.

Dla porównania, ustawa z dnia 17 maja 1989 r. o gwarancjach wolności sumienia i wyznania nie przewiduje generalnie żadnych bezwzględnych wymogów posiadania obywatelstwa polskiego dla członków organów kierowniczych związków wyznaniowych jako całości oraz ich ewentualnych terytorialnych jednostek organizacyjnych. Zgodnie $\mathrm{z}$ art. 14 ust. 4 tejże ustawy, przed objęciem stanowiska przez cudzoziemca, władze kościoła lub innego związku wyznaniowego powinny się upewnić, czy minister właściwy do spraw wyznań religijnych nie wyraża wobec tego zastrzeżeń. Niezgłoszenie zastrzeżeń w terminie 60 dni od daty powiadomienia uważa się za wyrażenie zgody. Ustawodawca nie przewidział jednak bezpośrednio konsekwencji braku owej zgody. W warunkach państwa prawnego nie można domniemywać sankcji nieważności nominacji, czy jej bezskuteczności. Mamy zatem do czynienia $\mathrm{z}$ luką w prawie.

Obszarem, w ramach którego odstępstwo od zasady równouprawnienia związków wyznaniowych bezpośrednio wiąże się z dyskryminacją ze względu na religię, jest świadczenie posług religijnych w tzw. zakładach zamkniętych. Równouprawnienie związków wyznaniowych oraz zasada równości wobec prawa i prawo do równego traktowania przez władze publiczne uzasadniają postulat jednakowo korzystnych dla wszystkich wspólnot religijnych reguł świadczenia posługi religijnej w tzw. placówkach zamkniętych, a zwłaszcza w szpitalach i w zakładach opieki społecznej. Najlepsze warunki prawne prowadzenia duszpasterstwa zapewniono Kościołowi Katolickiemu. Na mocy art. 17 ust. 3 Konkordatu z 1993 r. dla realizacji uprawnień do wykony-

${ }^{68}$ Zob. art. 5 i art. 6 rozporządzenia Prezydenta RP z dnia 22 marca 1928 r. o stosunku Państwa do Wschodniego Kościoła Staroobrzędowego nieposiadającego hierachji duchownej (Dz. U. Nr 38, poz. 363 z późn. zm.), art. 16 ustawy z dnia 21 kwietnia 1936 r. o stosunku Państwa do Karaimskiego Związku Religijnego w RP (Dz. U. Nr 30, poz. 241 z późn. zm.) i art. 23 ustawy z dnia 21 kwietnia 1936 r. o stosunku Państwa do Muzułmańskiego Związku Religijnego w RP (Dz. U. Nr 30, poz. 240 z późn. zm.). 
wania praktyk religijnych i korzystania z posług religijnych przez osoby przebywające w zakładach penitencjarnych, wychowawczych, resocjalizacyjnych oraz opieki zdrowotnej i społecznej, zarówno publicznych jak i prywatnych, podmioty prowadzące mają obowiązek zawarcia umowy z kapelanami, skierowanymi przez właściwego biskupa diecezjalnego. Chodzi tu zapewne przede wszystkim o odpłatne umowy o pracę, czy odpłatne świadczenie usług. Obowiązek zawarcia umów, o których mowa w art. 17 Konkordatu, spoczywa nawet na instytucjach należących do innych wspólnot religijnych, o ile z ich usług korzystają katolicy. O obligatoryjnym zatrudnieniu kapelanów katolickich mówi również art. 31 ust. 2 ustawy z 17 maja 1989 r. o stosunku Państwa do Kościoła Katolickiego w RP w odniesieniu do państwowych zakładów leczniczych oraz zamkniętych zakładów opieki społecznej. Zbliżone postanowienia sformułowano w art. 27 ust. 2 ustawy z 5 lipca 1991 r. o stosunku Państwa do Polskiego Autokefalicznego Kościoła Prawosławnego. W przypadku kapelanów pełniących posługę w zakładach penitencjarnych ustawodawca przewidział obowiązek zawarcia umów o nieodpłatne świadczenie usług.

W stosunku do ośmiu kościołów chrześcijańskich: katolickiego, prawosławnego, ewangelicko-augsburskiego, ewangelicko-metodystycznego, baptystycznego, adwentystycznego, polskokatolickiego i zielonoświątkowego, kierownicy państwowych zakładów opieki zdrowotnej i pomocy społecznej zostali zobowiązani do przeznaczenia odpowiednich pomieszczeń na kaplice lub - w wyjątkowych przypadkach - do udostępnienia innych pomieszczeń w celu umożliwienia organizowania nabożeństw i zbiorowych praktyk religijnych. Poza wyżej wymienionymi, żadnym innym związkom konfesyjnym nie stworzono równie stabilnych i korzystnych warunków prowadzenia działalności duszpasterskiej w omawianym zakresie.

Należy mocno podkreślić, że położenie związków wyznaniowych w Polsce pod względem zakresu ich uprawnień, a także pod względem gwarancji stabilności ich statusu prawnego - schematycznie ujmując rzeczywistość prawną - przypomina piramidę. Status Kościoła Katolickiego gwarantowany jest przez Konkordat z 28 lipca 1993 r., będący ratyfikowaną umową międzynarodową, za zgodą wyrażoną w ustawie, zatem konkordat ma pierwszeństwo przed ustawami, jeżeli postano- 
wień ustaw nie da się pogodzić z przepisami traktatu. Należy podkreślić, że traktat ze Stolicą Apostolską jest dość ogólny i fragmentaryczny. Nie gwarantuje on bezpośrednio licznych szczegółowych uprawnień, w tym finansowych, Kościoła Katolickiego i jego kleru. Drugą, istotną gwarancją formalno-prawną, jest szczególna ustawa z 17 maja 1989 r. o stosunku Państwa do Kościoła Katolickiego w Rzeczypospolitej Polskiej. Przez ponad 26 lat obowiązywania okazała się ona najkorzystniejszą indywidualną ustawą wyznaniową, zwłaszcza w kontekście tzw. restytucji (reprywatyzacji) własności nieruchomości na rzecz kościelnych osób prawnych.

Poniżej w piramidzie znajduje się druga kategoria, którą stanowi 14 kościołów i innych związków wyznaniowych, działających na podstawie indywidualnych aktów ustawodawczych z lat 1928-1997. Nie jest to grupa jednolita pod względem rodzaju i zakresu przyznanych uprawnień.

Najlepszą pozycję posiada Polski Autokefaliczny Kościół Prawosławny, działający na podstawie ustawy z dnia 4 lipca 1991 r. $^{69}$ Jest to regulacja prawna najbardziej zbliżona do ustawy o stosunku Państwa do Kościoła Katolickiego w RP, niekiedy wręcz posiadająca identyczne przepisy. Za PAKP lokuje się dziesięć innych związków wyznaniowych, działających na podstawie ustaw szczególnych z lat 1994-1997, których zarówno konstrukcja jak i treść wzorowane są na ustawie z 17 maja 1989 r. o stosunku Państwa do Kościoła Katolickiego w RP ${ }^{70}$.

${ }^{69}$ Zob.: ustawa z dnia 4 lipca 1991 r. o stosunku Państwa do Polskiego Autokefalicznego Kościoła Prawosławnego (tekst jedn. Dz. U. z 2014 r., poz. 1726)..

${ }^{70}$ Zob.: ustawa z dnia 13 maja 1994 r. o stosunku Państwa do Kościoła EwangelickoAugsburskiego w RP (tekst jedn. Dz. U. z 2015 r., poz. 43), ustawa z dnia 13 maja 1994 r. o stosunku Państwa do Kościoła Ewangelicko-Reformowanego w RP (tekst jedn. Dz. U. z 2014 r., poz. 498), ustawa z dnia 30 czerwca 1995 r. o stosunku Państwa do Kościoła Ewangelicko-Metodystycznego w RP (tekst jedn. Dz. U. z 2015 r., poz. 13), ustawa z dnia 30 czerwca 1995 r. o stosunku Państwa do Kościoła Chrześcijan Baptystów w RP (tekst jedn. Dz. U. z 2014 r., poz. 1889), ustawa z dnia 30 czerwca 1995 r. o stosunku Państwa do Kościoła Adwentystów Dnia Siódmego w RP (tekst jedn. Dz. U. z 2014 r., poz. 1888), ustawa z dnia 30 czerwca 1995 r. o stosunku Państwa do Kościoła Polskokatolickiego w RP (tekst jedn. Dz. U. z 2014 r., poz. 1559), ustawa z dnia 20 lutego 1997 r. o stosunku Państwa do Kościoła Katolickiego Mariawitów w RP (tekst jedn. Dz. U. z 2014 r., poz. 1712), ustawa z dnia 20 lutego 1997 r. o stosunku Państwa do Kościoła Starokatolickiego Mariawitów w RP (tekst jedn. Dz. U. z 2014 r., poz. 44), ustawa z dnia 20 lutego 1997 r. o stosunku Państwa do 
Znamienne jest, że po 20 lutego 1997 r., wbrew literze art. 25 ust. 5 Konstytucji z 1997 r., oraz pomimo wniosków szeregu zainteresowanych związków wyznaniowych, nastąpiła stagnacja indywidualnego ustawodawstwa wyznaniowego, określającego kompleksowo status poszczególnych wspólnot religijnych. Uzasadniona jest więc konstatacja, że art. 25 ust. 5 Konstytucji, przewidujący, że stosunki między państwem a nierzymskokatolickimi związkami wyznaniowymi regulowane będą obligatoryjnie w drodze ustaw, uchwalonych na podstawie umów zawartych przez Radę Ministrów z ich właściwymi przedstawicielami, okazał się martwym przepisem ustawy zasadniczej ${ }^{71}$.

Specyficzną grupę, w ramach omawianej kategorii związków wyznaniowych, stanowią trzy niechrześcijańskie związki wyznaniowe, formalnie wciąż działające na podstawie przedwojennych aktów ustawodawczych. Są to Wschodni Kościół Staroobrzędowy nieposiadający hierarchii duchownej, Karaimski Związek Religijny i Muzułmański Związek Religijny. Właściwe, indywidualne akty prawne są anachroniczne, odnoszą się bowiem do terytorium Polski sprzed 1 września 1939 r. Uzasadnione wątpliwości wzbudza zgodność szeregu ich istotnych postanowień z Konstytucją z 1997 r., aczkolwiek wciąż korzystają one formalnie $\mathrm{z}$ domniemania konstytucyjności. Niektóre istotne postanowienia tych aktów ustawodawczych od lat nie są stosowane przez centralną administrację wyznaniową. Taki stan rzeczy jest niezgodny z konstytucyjną zasadą określoności prawa, z zasadą demokratycznego państwa prawnego, z zasadą zaufania obywateli do państwa i stanowionego przezeń prawa, z utrwalonym orzecznictwem Trybunału Konstytucyjnego. Dlatego też wyznawcy rzeczonych związków wyznaniowych nie mają elementarnej pewności co do zakresu przysługujących im uprawnień z zakresu wolności sumienia i wyznania, szczególnie w aspekcie kolektywnej wolności uzewnętrzniania religii. Omawiane powyżej akty ustawodawcze zostały wydane

gmin wyznaniowych żydowskich w RP i ustawa z dnia 20 lutego 1997 r. o stosunku Państwa do Kościoła Zielonoświątkowego w RP (tekst jedn. Dz. U. z 2015 r., poz. 14).

${ }^{71}$ Wyjątkiem potwierdzającym regułę okazała się szczegółowa ustawa z 13 maja $2011 \mathrm{r}$. o finansowaniu Prawosławnego Seminarium Duchownego w Warszawie z budżetu państwa (Dz. U. Nr 144, poz. 849). 
w warunkach autorytarnego państwa, jakim była II Rzeczypospolita w latach 1926-1939.

To, co łączy owe czternaście związków wyznaniowych, to formalnie dobre gwarancje stabilności ich sytuacji prawnej. Zgodnie z art. 25 ust. 5 Konstytucji, każda poważniejsza zmiana indywidualnych aktów ustawodawczych wymaga uprzedniej zgody właściwego związ$\mathrm{ku}$ wyznaniowego, wyrażonej $\mathrm{w}$ formie umowy zawartej $\mathrm{z}$ Radą Ministrów. Wspólnoty religijne mogą wyegzekwować swoje uprawnienia w wyniku wystąpienia do Trybunału Konstytucyjnego z wnioskami o stwierdzenie niekonstytucyjności ustaw uchwalonych niezgodnie $\mathrm{z}$ art. 25 ust. 5 Konstytucji.

Trzecią kategorię związków wyznaniowych stanowią związki wyznaniowe i organizacje międzykościelne wpisane do rejestru kościołów i innych związków wyznaniowych, prowadzonego przez ministra właściwego ds. wyznań religijnych. Korzystają one z uprawnień określonych w ustawie z dnia 17 maja 1989 r. o gwarancjach wolności sumienia i wyznania. Nie mają one jednak tak dobrych gwarancji stabilności sytuacji prawnej, jak związki wyznaniowe działające na podstawie indywidualnych aktów normatywnych. W doktrynie prawa wyznaniowego, jak również w praktyce legislacyjnej przeważa stanowisko, że zmiana ustawy o gwarancjach wolności sumienia i wyznania, w tym umniejszenie uprawnień związków wyznaniowych, nie wymaga ich uprzedniej zgody, a jedynie - co najwyżej - zasięgnięcia opinii, przedstawiona zaś przez związek wyznaniowy opinia nie ma dla organów państwa charakteru prawnie wiążącego. Opisany powyżej status posiadają obecnie 162 związki wyznaniowe i pięć organizacji międzykościelnych $^{72}$. W opinii administracji wyznaniowej oraz przeważającej części przedstawicieli doktryny prawa wyznaniowego tylko wspólnoty religijne, które są zarejestrowane jako związki wyznaniowe (organizacje międzykościelne) albo posiadają status prawny określony przez indywidualne akty ustawodawcze, mogą korzystać ze specjalnych uprawnień, przyznanych przez prawo polskie związkom wyznaniowym, jako pewnemu typowi korporacji. Związki wyznaniowe podlegają szczególnej kontroli przede wszystkim przy okazji aktu rejestracji.

${ }^{72}$ Zob. https://mac.gov.pl/files/ost._e-rejestr_hw_23.06.2015.pdf [dostęp: 7.07.2015]. 
Personifikując państwo i jego prawo, zarówno formalnie jak i w praktyce obdarzają oficjalnie działające kościoły i inne związki wyznaniowe bardzo daleko idącym, nie zawsze uzasadnionym, zaufaniem.

Kolejną kategorię wspólnot religijnych stanowią korporacje posiadające osobowość prawną, występujące w obrocie prawnym jako stowarzyszenia, zarejestrowane na podstawie ustawy z dnia 7 kwietnia 1989 r. - Prawo o stowarzyszeniach ${ }^{73}$, albo występujące jako fundacje - na podstawie ustawy z dnia 6 kwietnia 1984 r. o fundacjach ${ }^{74}$. Liczba tego rodzaju wspólnot religijnych jest bliżej nieokreślona, ale niewątpliwie one istnieją. Ich status prawny jest obecnie poniekąd równy ze statusem tzw. organizacji laickich. Nie mogą owe wspólnoty religijne, pomimo że mają w istocie charakter wyznaniowy, korzystać ze specjalnych uprawnień (przywilejów) przyznanych związkom wyznaniowym. Wydaje się, że owa grupa związków wyznaniowych, działających jako fundacje czy stowarzyszenia wpisane do Krajowego Rejestru Sądowego, podlega - już po samym akcie rejestracji - najdalej idącej kontroli ze strony organów państwa (sądu rejestrowego). Jest to kontrola szczegółowa i prowadzona na bieżąco.

Jest wreszcie grupa wspólnot religijnych działających nieformalnie - nieposiadających osobowości prawnej. Na rzecz tych wspólnot składniki majątku nabywają osoby fizyczne, zwłaszcza ich liderzy. Grupa tych wspólnot z jednej strony nie posiada żadnych szczególnych uprawnień, z drugiej strony jednocześnie podlega minimalnej kontroli ze strony organów władzy publicznej.

Przyjęta przez polskiego ustawodawcę jeszcze w okresie międzywojennym (1918-1939), a podtrzymana w okresie Polski Ludowej i kontynuowana w III RP metoda regulacji sytuacji prawnej związków wyznaniowych w drodze indywidualnych aktów ustawodawczych, nie tylko nie sprzyja urzeczywistnieniu zasady równouprawnienia związków wyznaniowych, ale czyni tę zasadę wręcz niemożliwą do realizacji. Obie rzeczone zasady stosunków wyznaniowych zostały jednak potwierdzone w art. 25 ust. 1, 4 i 5 Konstytucji z 1997 r. Ustawodawca ma więc konstytucyjny obowiązek czynić realne starania na rzecz ich

\footnotetext{
${ }^{73}$ Tekst jedn. Dz. U. z 2001 r., Nr 79, poz. 855 z późn. zm.

${ }^{74}$ Tekst jedn. Dz. U. z 1991 r., Nr 46, poz. 203 z późn. zm.
} 
urzeczywistnienia. Tymczasem - jak pokazuje praktyka - ustawodawca urzeczywistnia zasadę równouprawnienia związków wyznaniowych niekonsekwentnie i selektywnie.

VI. PRAWNE ŚRODKI ZWALCZANIA DYSKRYMINACJI ZE WZGLĘDU NA PRZEKONANIA W SPRAWACH RELIGIJNYCH - WYBRANE ZAGADNIENIA

Konstytucja RP w art. 77 ust. 2 formułuje ogólny zakaz, iż [u]stawa nie może nikomu zamykać drogi sądowej dochodzenia naruszonych wolności lub praw. Nie jest to jednak równoznaczne z obowiązkiem zapewnienia szybkiej i skutecznej drogi sądowej dochodzenia owych wolności i praw, w szczególności - zapewnienia niedyskryminacji ze względu na religię lub przekonania.

Przewidzianą w art. 79 ust. 1 Konstytucji RP instytucję skargi konstytucyjnej, jako instrument walki z dyskryminacją jednostki czy grup ludzkich, m.in. ze względu na wyznanie lub światopogląd (bezwyznaniowość), należy uznać za zbyt mało efektywną. Polski ustrojodawca przyjął „wąską” koncepcję skargi konstytucyjnej. Jej zastosowanie jest obwarowane dużą liczbą wymogów formalnych. Przesłanką wniesienia skargi jest ostateczność orzeczenia sądu, czy organu administracji publicznej w sprawie wolności, praw lub obowiązków danej osoby, określonych w Konstytucji. Trybunał Konstytucyjny bada nie tyle konstytucyjność owego orzeczenia, lecz konstytucyjność jego podstawy normatywnej. Stwierdzenie niekonstytucyjności aktu normatywnego, naruszającego zakaz dyskryminacji nie gwarantuje, że szybko zostaną usunięte jego skutki wobec konkretnego człowieka, czy grupy. Orzeczenie uwzględniające skargę konstytucyjną co prawda eliminuje kwestionowany akt prawny z systemu prawnego, ale nadal może stanowić podstawę do wznowienia postępowania w danej sprawie, zaś wynik postępowania nie jest przesądzony. Dalszą, cywilnoprawną konsekwencją rozstrzygnięcia $\mathrm{TK}$, jest powstanie roszczenia o naprawienie szkody wyrządzonej przez wydanie aktu normatywnego. Podstawą prawną takiego roszczenia jest art. $417^{1} \S 1$ Kodeksu cywilnego. Sprawa może trwać latami. Związkom wyznaniowym służy co prawda uprawnienie 
do wniesienia wniosku o stwierdzenie niekonstytucyjności aktu normatywnego dotyczącego ich zakresu działania, w szczególności ze względu na naruszenia art. 32 ust. 2 (zakaz dyskryminacji), lub art. 25 ust. 1 (zasada równouprawnienia związków wyznaniowych), ale w ciągu 26 lat istnienia opisanego uprawnienia proceduralnego zdarzył się tylko jeden przypadek, że Trybunał Konstytucyjny uznał zasadność wniosku dotyczącego niekonstytucyjności. Nigdy Trybunał nie podzielił zarzutu o naruszenie zasady niedyskryminacji, czy zasady równouprawnienia związków wyznaniowych.

Uchwalony 16 grudnia 1966 r. w Nowym Jorku Pierwszy Protokół Fakultatywny do MPPOiP, ratyfikowany został przez Polskę 7 listopada 1991 r., przewiduje instytucję skargi prywatnej obywatela przeciwko państwu, które naruszyło prawa człowieka wobec skarżącego, o ile jest ono stroną Protokołu. Skargę rozpatruje Komitet Praw Człowieka na posiedzeniu przy drzwiach zamkniętych. Skarga musi spełniać kilka podstawowych warunków:

1) powinna być nieanonimowa,

2) powinna być należycie udokumentowana; przed jej złożeniem należy wyczerpać wszystkie dostępne wewnątrzkrajowe środki zaradcze,

3) ta sama sprawa nie może być równocześnie rozpatrywana w ramach innej procedury międzynarodowego badania lub rozstrzygania sporów,

4) treść skargi powinna dotyczyć naruszenia prawa gwarantowanego przez Pakt.

O skardze, uznanej wstępnie za zasadną, Komitet powiadamia państwo, któremu postawiono zarzuty, zaś państwo ma przedstawić Komitetowi w ciągu 6 miesięcy pisemne wyjaśnienia lub oświadczenia naświetlajace sprawę oraz wskazujące ewentualne środki zaradcze, jakie mogłyby być przez nie podjęte. Swój pogląd na sprawę Komitet przekazuje stronom sporu oraz włącza go do swego rocznego sprawozdania, wedle 45 artykułu Paktu.

Zarzut naruszenia zakazu dyskryminacji w ujęciu art. 14 EKPCz może być podstawą skargi do Europejskiego Trybunału Praw Człowieka w Strasburgu. Należy jednak również pamiętać o licznych kryteriach formalnych dla skutecznego złożenia skargi do ETPCz, przede 
wszystkim o tym, że przed ETPCz można skarżyć tylko państwo-stronę Konwencji. Niedopuszczalne są skargi kierowane przeciwko osobom prywatnym (np. pracodawcom prywatnym), instytucjom państwowym, fundacjom czy związkom wyznaniowym.

Naruszenie prawa gwarantowanego przez Konwencję musi mieć miejsce po wejściu w życie Konwencji w stosunku do Polski, czyli od 1 maja 1993 r. Skarżący ma obowiązek wyczerpania krajowych środków odwoławczych. Skargę należy złożyć w ciągu sześciu miesięcy od wydania, czyli w istocie doręczenia, ostatecznego (ostatniego) orzeczenia w sprawie, przy czym w warunkach polskich należy także skorzystać z możliwości wniesienia skargi konstytucyjnej ${ }^{75}$. W skardze należy wskazać, jakie prawo - gwarantowane przez Konwencję zostało naruszone działaniem (lub zaniechaniem) władzy publicznej. Europejski Trybunał Praw Człowieka nie rozpatruje spraw, jeżeli zostały one poddane innej międzynarodowej procedurze dochodzenia czy też rozstrzygnięciu (art. 35 ust. 2 EKPCz) ${ }^{76}$.

Należy zaakcentować, że Protokół nr 14 do EKPCz, który wszedł w życie w dniu 1 czerwca 2010 roku, wprowadził nowe, uznaniowe w istocie, materialne kryterium dopuszczalności skargi tzw. „znaczący uszczerbek". Trybunał uzna za niedopuszczalną każdą skargę indywidualną w przypadku, gdy wnioskodawca nie doznał znaczącego uszczerbku, chyba że poszanowanie praw człowieka w rozumieniu EKPCz i jej Protokołów wymaga rozpoznania przedmiotu skargi, oraz pod warunkiem, że sprawa, która nie została należycie rozpatrzona przez sąd krajowy, nie może być odrzucona na tej podstawie (zob. obecny art. 35 ust. 3 lit. b EKPCz) ${ }^{77}$. Reasumując, należy stwierdzić, że przyjęcie skargi do rozpatrzenia przez ETPCz ze względu na zarzut naruszenia art. 14 Konwencji, czyli zarzut dyskryminacji ze względu

${ }^{75} \mathrm{~W}$ przypadku skargi na przewlekłość postępowania sądowego na podst. art. 6 ust. 1 Europejskiej Konwencji osoby chcące wnieść skargę do Trybunału muszą najpierw zaskarżyć przewlekłość postępowania do sądu polskiego.

${ }^{76}$ Por. http://bip.ms.gov.pl/pl/prawa-czlowieka/europejski-trybunal-praw-czlowieka/ podstawowe-informacje-dotyczace-skladania-skargi-do-europejskiego-trybunalu-prawczlowieka/warunki-dopuszczalnosci-skargi/ [dostęp: 16.07.2015].

${ }^{77}$ Zob. http://bip.mkidn.gov.pl/media/download_gallery/20141028Protokol_nr_14.pdf [dostęp: 16.07.2015]. 
na religię lub światopogląd, jest niepewne. Samo postępowanie przed Trybunałem trwa kilka lat. Usunięcie stanu prawnego stanowiącego podstawę dyskryminacji, nawet w przypadku wyroku skazującego Polskę, może trwać latami.

Naruszenie zakazu dyskryminacji ze względu zwłaszcza na religię lub światopogląd, jako pogwałcenie jednej z naczelnych wartości UE, może potencjalnie skutkować zawieszeniem Polski w niektórych prawach członkowskich. Decyzja w tym zakresie miałaby jednak charakter w dużej mierze polityczny, a nie wyłącznie prawny. Zgodnie z art. 7 ust. 1 Traktatu o Unii Europejskiej na uzasadniony wniosek jednej trzeciej państw członkowskich, Parlamentu Europejskiego lub Komisji Europejskiej, Rada, stanowiąc większością czterech piątych swych członków po uzyskaniu zgody Parlamentu Europejskiego, może stwierdzić istnienie wyraźnego ryzyka poważnego naruszenia przez państwo członkowskie wartości, o których mowa w artykule 2 TUE. Przed dokonaniem takiego stwierdzenia Rada wysłuchuje dane państwo członkowskie i - stanowiąc zgodnie z tą samą procedurą może skierować do niego zalecenia. Ponadto Rada regularnie bada, czy powody dokonania takiego stwierdzenia pozostają aktualne. W następstwie tego Rada Europejska, stanowiąc jednomyślnie na wniosek jednej trzeciej państw członkowskich lub Komisji Europejskiej i po uzyskaniu zgody Parlamentu Europejskiego, może stwierdzić - po wezwaniu państwa członkowskiego do przedstawienia swoich uwag - poważne i stałe naruszenie przez państwo członkowskie wartości, o których mowa w artykule 2 (art. 7 ust. 2). Po dokonaniu stwierdzenia na mocy ustępu 2, Rada, stanowiąc większością kwalifikowaną, może zdecydować o zawieszeniu niektórych praw - wynikających ze stosowania Traktatów - dla tego państwa członkowskiego, łącznie z prawem do głosowania przedstawiciela rządu tego państwa członkowskiego w Radzie. Rada uwzględnia przy tym możliwe skutki takiego zawieszenia dla praw i obowiązków osób fizycznych i prawnych. Należy podkreślić, że obowiązki, które ciążą na państwie członkowskim na mocy Traktatów, pozostają w każdym przypadku wiążące dla tego państwa.

Reasumując, aby znalazły zastosowanie sankcje przewidziane w art. 7 TUE, skala naruszenia zakazu niedyskryminacji ze względu 
na omawiane kryteria musiałaby mieć charakter jaskrawy, długotrwały i masowy. Uruchomienie skutecznej procedury odpowiedzialności państwa polskiego na podstawie TUE, zdecydowanie przekracza możliwości jednostki. Spośród podmiotów pozapaństwowych być może mogłyby to zapoczątkować wpływowe organizacje pozarządowe np. Helsińska Fundacja Praw Człowieka, czy relatywnie duże kościoły i inne związki wyznaniowe, działające kolektywnie. Sama procedura jawi się jako długotrwała i nigdy dotychczas nie znalazła zastosowania.

Kodeks pracy przewiduje w art. $18^{3 \mathrm{~d}}$ iż osoba, wobec której pracodawca naruszył zasadę równego traktowania w zatrudnieniu, ma prawo do odszkodowania w wysokości nie niższej niż minimalne wynagrodzenie za pracę, ustalane na podstawie odrębnych przepisów. Zgodnie $\mathrm{z}$ art. $18^{3 \mathrm{e}} \S 1 \mathrm{KP}$ skorzystanie przez pracownika $\mathrm{z}$ uprawnień, przysługujących z tytułu naruszenia zasady równego traktowania w zatrudnieniu, nie może być podstawą niekorzystnego traktowania pracownika, a także nie może powodować jakichkolwiek negatywnych konsekwencji wobec pracownika, nie może stanowić zwłaszcza przyczyny uzasadniającej wypowiedzenie przez pracodawcę stosunku pracy, lub jego rozwiązanie bez wypowiedzenia. Omawiany przepis stosuje się także do pracownika, który udzielił w jakiejkolwiek formie wsparcia pracownikowi korzystającemu z uprawnień przysługujących z tytułu naruszenia zasady równego traktowania w zatrudnieniu (art. 18 § $2 \mathrm{KP}$ ).

Szczególne gwarancje proceduralne służące zwalczaniu dyskryminacji ze względu na religię, wyznanie, czy światopogląd zawiera ustawa ,antydyskryminacyjna” z 2010 r. Zgodnie z jej art. 13 ust. 1 każdy, wobec kogo zasada równego traktowania została naruszona, ma prawo do odszkodowania. Ustawa ,,antydyskryminacyjna” nie przewiduje jednak samoistnej skargi przeciwko zakazanej dyskryminacji m.in. ze względu na religię, wyznanie i światopogląd. W sprawach naruszenia zasady równego traktowania stosuje się przepisy ustawy z dnia 23 kwietnia 1964 r. - Kodeks cywilny ${ }^{78}$. Natomiast w aspekcie proceduralnym zgodnie $\mathrm{z}$ art. 14 ust. 1 rzeczonej ustawy stosuje się przepisy ustawy z dnia 17 listopada 1964 r. - Kodeks postępowania cywilne-

${ }^{78}$ Dz. U. Nr 16, poz. 93 z późn. zm. 
go $^{79}$. Podkreślić należy, że istotnym ułatwieniem dla poszkodowanego jest zwolnienie go z obowiązku udowodnienia dyskryminacji, ma on obowiązek jedynie uprawdopodobnienia tego faktu (art. 14 ust. 2). Natomiast ten, komu zarzucono naruszenie zakazu dyskryminacji, jest obowiązany wykazać, że nie dopuścił się naruszenia zasady równego traktowania.

Zgodnie z art. 15 ustawy z 3 grudnia 2010 r. termin przedawnienia roszczeń z tytułu naruszenia zasady równego traktowania trwa trzy lata od dnia powzięcia przez poszkodowanego wiadomości o naruszeniu zasady równego traktowania, i nie dłużej niż 5 lat od zaistnienia zdarzenia stanowiącego naruszenie tej zasady. Zastrzega przy tym ustawodawca, że dochodzenie roszczeń na podstawie niniejszej ustawy nie pozbawia poszkodowanego prawa do dochodzenia roszczeń na podstawie przepisów innych ustaw (art. 16). W celu zapewnienia dodatkowych gwarancji skutecznego zwalczania dyskryminacji, art. 17 ust. 1 rzeczonej ustawy konstatuje, iż skorzystanie z uprawnień przysługujących $\mathrm{z}$ tytułu naruszenia zasady równego traktowania nie może być podstawą niekorzystnego traktowania, a także nie może powodować jakichkolwiek negatywnych konsekwencji wobec tego, kto z nich skorzystał. Wymienioną regułę stosuje się również do tego, kto udzielił w jakiejkolwiek formie wsparcia korzystającemu z uprawnień przysługujących z tytułu naruszenia zasady równego traktowania (art. 17 ust. 2). Do przypadków, o których mowa w ust. 1 i 2, mają zastosowanie przepisy art. 13-15.

Ponadto w przypadku naruszenia zakazu dyskryminacji ze względu na religię lub przekonania zasadne wydaje się dochodzenie roszczeń cywilnoprawnych na podstawie art. $23 \mathrm{i}$ art. 24 Kodeksu cywilnego (KC). Rzeczona dyskryminacja godzi bowiem bezpośrednio w swobodę sumienia jednostki, czyli w jedno z dóbr osobistych wymienionych w art. $23 \mathrm{KC}$. Stanowi formę presji na zainteresowanego skłaniając go do przynajmniej milczącej aprobaty przekonań religijnych (światopoglądowych) dominujących $\mathrm{w}$ danym środowisku. Zatem zgodnie z ogólnymi postanowieniami art. $24 \S 1 \mathrm{KC}$ ten, czyje dobro osobiste zostaje zagrożone cudzym działaniem, może żądać zaniechania

${ }^{79}$ Dz. U. Nr 43, poz. 296 z późn. zm. 
tego działania, chyba że nie jest ono bezprawne. W razie dokonanego naruszenia może on także żądać, ażeby osoba, która dopuściła się naruszenia, dopełniła czynności potrzebnych do usunięcia jego skutków, w szczególności ażeby złożyła oświadczenie odpowiedniej treści i w odpowiedniej formie. Na zasadach przewidzianych w Kodeksie cywilnym może on również żądać zadośćuczynienia pieniężnego lub zapłaty odpowiedniej sumy pieniężnej na wskazany cel społeczny (zob. art. $448 \mathrm{KC} \mathrm{w} \mathrm{zw.} \mathrm{z} \mathrm{art.} 445 \mathrm{KC}$ ). Ponadto jeżeli wskutek naruszenia dobra osobistego została wyrządzona szkoda majątkowa, poszkodowany może żądać jej naprawienia na zasadach ogólnych (zob. m.in. art. 415-417 $7^{1} \mathrm{KC}$, art. $430 \mathrm{KC}$, art. 441-442 ${ }^{1} \mathrm{KC}$ ). Przesłanką wniesienia roszczenia na podstawie art. $24 \S 1 \mathrm{KC}$ jest już samo zagrożenie swobody sumienia. Należy wszakże podkreślić, że ciężar dowodu zgodnie z ogólnymi zasadami postępowania cywilnego spoczywa na pozywającym (pokrzywdzonym).

VII. PODSUMOWANIE

We współczesnym prawie polskim występują dwie przeciwstawne tendencje, widoczne już na poziomie ustrojowym. Czytelne jest dążenie do wyeliminowania dyskryminacji ze względu na przekonania w sprawach religijnych we wszystkich dziedzinach życia jednostki, z wyjątkiem życia prywatnego. Gwarancje mają zarówno charakter generalny jak i szczegółowy, szczególnie w szeroko rozumianej dziedzinie zatrudnienia. Zarazem wyraźnie występuje zjawisko dyskryminacji $\mathrm{w}$ dziedzinie ochrony prawnej oraz w dziedzinie wolności uzewnętrzniania przekonań w sprawach religijnych osób wyznających światopogląd niereligijny. Zdecydowanie niedowartościowane prawnie, w porównaniu ze związkami wyznaniowymi, są tzw. organizacje laickie $^{80}$. O ile w świetle Konstytucji RP (art. 25 ust. 3 w zw. z ust. 4 i 5) czy ustawy o gwarancjach wolności sumienia i wyznania (art.: 16, 16a, 17) związki wyznaniowe urastają wręcz do kategorii

${ }^{80}$ Por. Paweł Borecki, „Status prawny osób bezwyznaniowych w Polsce,” Państwo i Prawo 4 (2007): 16-30. 
partnerów państwa, szczególnie w polityce społecznej, to korporacje oparte na kryterium światopoglądu - mogą uzyskać w praktyce jedynie status stowarzyszeń, względnie fundacji, w dziedzinie zaś finansowej - co najwyżej status organizacji pożytku publicznego i wówczas podlegają szczegółowej kontroli państwa. Prawo karne zapewnia szczególną ochronę jedynie osobom religijnym, czyni to poprzez kryminalizację przestępstwa tzw. obrazy uczuć religijnych. Zjawisko dyskryminacji (nierównego traktowania) ze względu na wyznanie występuje także pomiędzy wyznawcami różnych związków wyznaniowych w Polsce. Wiąże się ono ściśle ze zróżnicowaniem sytuacji prawnej związków wyznaniowych. Należy zaznaczyć, że optymalne położenie prawne i faktyczne posiadają wyznawcy największych i najstarszych kościołów chrześcijańskich, które uzyskały indywidualną regulację ustawową w latach 1989-1997. Utrzymywaniu, jeśli nie narastaniu zjawiska dyskryminacji, sprzyja metoda indywidualnej ustawowej regulacji statusu poszczególnych związków wyznaniowych.

We współczesnym polskim prawie brak jest instytucji indywidualnej skargi sądowej zarówno przeciwko dyskryminacji w ogóle, jak i przeciwko dyskryminacji ze względu na religię lub światopogląd (bezwyznaniowość) w sferze życia poza-prywatnego. Należy, poza postulatem jej wprowadzenia, opowiedzieć się za ułatwieniami dowodowymi w zakresie dochodzenia roszczeń z tego tytułu. Skarżący winien jedynie uprawdopodobnić zasadność zarzutu, zaś ciężar dowodu, iż do dyskryminacji nie doszło, należy przenieść na podmiot obciążony zarzutem. Ma on z reguły silniejszą pozycję faktyczną. Ofierze należy jednoznacznie stworzyć możliwość dochodzenia zadośćuczynienia za krzywdę i odszkodowania za szkodę materialną. Zasadne jest zatem znowelizowanie art. 194 k.k., przewidującego kryminalizację nierównego traktowania ze względu na wyznanie lub bezwyznaniowość.

Niewątpliwie przystąpienie Polski do UE z dniem 1 maja 2005 r. zwiększyło poziom ochrony przed dyskryminacją ze względu na religię (wyznanie) lub światopogląd (bezwyznaniowość). Polska musiała urzeczywistnić w swoim prawie krajowym w szczególności standardy zwalczania rzeczonego zjawiska, przewidziane w Dyrektywie Rady 2000/78/WE z dnia 27 listopada 2000 r., ustanawiającej ogólne warunki ramowe równego traktowania w zakresie zatrudnienia i pracy. 
Bardzo istotna poprawa $\mathrm{w}$ zakresie gwarancji niedyskryminacji jednostek i grup osób ze względu na religię lub światopogląd nastąpi wraz z ratyfikacją przez Polskę Protokołu 12 do EKPCz. Ratyfikacja stworzy możliwość, w ramach polskiego systemu prawa, wnoszenia skarg do ETPCz w oparciu o zarzut dyskryminacji m.in. ze względu na religię lub przekonania. Należy jednak pamiętać, że przyjęcie skargi przez ETPCz ma w istotnej mierze charakter uznaniowy, a samo postępowanie przed Trybunałem trwa latami.

Wskazane jest znowelizowanie ustawy z 17 maja 1989 r. o gwarancjach wolności sumienia i wyznania w celu urealnienia szeregu jej norm, poprzez wprowadzenie ogólnej reguły przewidującej - za naruszenie jej postanowień, w tym dotyczących zakazu dyskryminacji ze względu na wyznanie lub światopogląd - karę grzywny, ograniczenia wolności lub pozbawienia wolności do lat dwóch. Postulowana zmiana pozwoliłaby urealnić przede wszystkim zasadę państwa świeckiego, neutralnego wobec religii i przekonań, czyli pośrednie gwarancje niedyskryminacji ze względu na przekonania w sprawach religijnych.

Należy znowelizować indywidualne ustawy wyznaniowe eliminując $\mathrm{z}$ nich przepisy o charakterze dyskryminacyjnym. Konieczne jest uchylenie szczególnych ograniczeń ustawodawczych dotyczących członkostwa w gminach wyznaniowych żydowskich. Należy stworzyć identyczne preferencje podatkowe dla działalności charytatywno-opiekuńczej prowadzonej przez osoby prawne wszystkich oficjalnie działających związków wyznaniowych. Prawo do udzielania małżeństw ze skutkami cywilnymi vel małżeństw cywilnych w formie wyznaniowej powinno być przyznane wszystkim związkom wyznaniowym - zarówno wpisanym do właściwego rejestru jak i działającym na podstawie odrębnych aktów ustawodawczych.

Ponadto należy dążyć do ustawowego równouprawnienia ze związkami wyznaniowymi tzw. organizacji laickich, zorganizowanych na podstawie światopoglądu. Konieczne będzie zatem m.in. rozszerzenie na organizacje laickie szczegółowych postanowień ustawy o gwarancjach wolności sumienia i wyznania, poświęconych obecnie jedynie związkom wyznaniowym. W konsekwencji zasadny jest postulat gruntownej zmiany charakteru dotychczasowego rejestru kościołów 
i innych związków wyznaniowych poprzez dopuszczenie - na równi do rejestracji tzw. organizacji laickich.

Reasumując, mimo licznych deklaracji zakazujących dyskryminacji ze względu na wyznanie lub światopogląd w prawie polskim, dyskryminacja tego rodzaju występuje w licznych postanowieniach prawa obowiązującego. Rzuca się w oczy szczególnie niedowartościowanie w wymiarze prawnym osób bezwyznaniowych w stosunku do osób należących do związków wyznaniowych w dziedzinie szeroko rozumianych gwarancji wolności myśli, sumienia i wyznania. Wyraźne jest upośledzenie położenia prawnego tzw. organizacji laickich w porównaniu do statusu związków wyznaniowych. Kierunek przemian religijno-społecznych wskazuje, że wspomniana kwestia może stać się jednym z czołowych problemów w dziedzinie prawa wyznaniowego w Polsce. Brak jest środków prawnych (procesowych), może poza postanowieniami art. 194 k.k., pozwalających szybko i skutecznie zwalczać zjawisko dyskryminacji ze względu na religię lub światopogląd w sposób całościowy na szczeblu krajowym. Poszkodowanym pozostają zatem w dużej mierze jedynie środki pozaprawne - odwołanie się do środków masowego przekazu, indywidualne i zbiorowe protesty publiczne, czy próby dotarcia do decydentów politycznych różnego szczebla.

\section{BIBLIOGRAFIA}

Borecki, Paweł. „Status prawny osób bezwyznaniowych w Polsce.” Państwo i Prawo 4 (2007): 16-30.

Borecki, Paweł. „Dopuszczalna wysokość odliczeń darowizn na działalność charytatywno-opiekuńczą kościołów - glosa do uchwały NSA z 14.03.2004 r., (FPS 5/04)." Glosa 2 (2006): 119-131.

Borecki, Paweł. „Wielka Polska Katolicka.” Forum Klubowe. Dwumiesięcznik klubów dyskusyjnych lewicy 3-4 (2006): 34-41.

Kłączyńska, Natalia. „Prawnokarne znaczenie norm zawierających zakaz dyskryminacji." Nowa Kodyfikacja Prawa Karnego 12 (2003): 53-66.

Konwencja o Ochronie Praw Człowieka i Podstawowych Wolności. Komentarz do artykutów 1-18. Tom I, red. Lech Garlicki. Warszawa: C.H. Beck, 2010. 
Kruczoń, Erwin. „Przestępstwo obrazy uczuć religijnych.” Prokuratura i Prawo 2 (2011): 38-59.

Obirek, Stanisław. Polak katolik? Warszawa: Wydawnictwo CiS, 2015.

Pietrzak, Michał. Prawo wyznaniowe. Warszawa: LexisNexis, 2010.

Pietrzak, Michał. „Geneza ustaw wyznaniowych z 17 maja 1989 r.” W:

Prawo wyznaniowe $w$ Polsce (1989-2009). Analizy-dyskusje-postulaty, red. Dariusz Walencik, 11-26. Katowice - Bielsko-Biała: Wyższa Szkoła Bakowości i Finansów w Bielsku-Białej, 2009.

Winczorek, Piotr. Komentarz do Konstytucji Rzeczypospolitej Polskiej z dnia 2 kwietnia 1997 r. Warszawa: Liber, 2000.

Winiarczyk-Kossakowska, Małgorzata. Państwowe prawo wyznaniowe w praktyce administracyjnej. Warszawa: Scholar, 1999.

Wolność religii. Wybór materiałów. Dokumenty. Orzecznictwo, tłum. i oprac. Tadeusz Jasudowicz. Toruń: „Dom Organizatora” TNOiK, 2001.

Zieliński, Tadeusz J. „Ustawa o gwarancjach wolności sumienia i wyznania jako „magna charta” swobód światopoglądowych w Polsce." W: Prawo wyznaniowe $w$ Polsce (1989-2009). Analizy-dyskusje-postulaty, red. Dariusz Walencik, 53-65. Katowice - Bielsko-Biała: Wyższa Szkoła Bakowości i Finansów w Bielsku-Białej, 2009.

\section{PROHIBITION OF DISCRIMINATION ON GROUNDS OF RELIGION OR BELIEFS IN THE POLISH LAW}

\section{Summary}

In the contemporary Polish law, there are two opposing trends already visible in the Constitution of 1997. Clear is to strive to eliminate discrimination based on belief in religious matters in all areas of the unit, with the exceptionpretty private life. Guarantees are both of a general nature and detail, especially in the wider field of employment. At the same time clearly the phenomenon of discrimination in the field of legal protection and in the field of freedom to manifest one's beliefs in religious matters irreligious people professing belief.

The phenomenon of discrimination (unequal treatment) because of religion there is so-that between followers of different religious communities in Poland. It is connected closely with the diversity of the legal status of religious organizations. It should be noted that the optimum position of the legal and factual 
followers have the largest and oldest Christian Regarding the Church-hunt, which received individual statutory regulation in 1989-1997.

Poland, to better prevent unequal treatment on grounds of religion or believe should sign and ratify Protocol No. 12 to the Convention for the Protection of Human Rights and Fundamental Freedoms.

Ttumaczenie własne autora

Key words: prohibition of discrimination, freedom of conscience and religion, religious denomination, equality, The Polish Constitution of 1997

Słowa kluczowe: zakaz dyskryminacji, wolność sumienia i wyznania, związki wyznaniowe, równe traktowanie, Konstytucja RP z 1997 r. 